\title{
A quebra do paradigma "Sentido Da Colonização": notas sobre o debate historiográfico do Brasil Colonial, Antigo Sistema Colonial e Antigo Regime nos Trópicos.
}

Breaking the paradigm "Sentido Da Colonização": notes related to the historiographical debate about Colonial Brazil, Old Colonial System and Old Regime In The Tropics.

DOI: http://dx.doi.org/10.1590/2236-463320171507

\section{Wesley Dartagnan Salles \\ Universidade de São Paulo - USP, São Paulo - SP, Brasil \\ wesleysalles@usp.br}

Resumo: Este artigo retoma as bases historiográficas de duas correntes brasileiras: Antigo Sistema Colonial e Antigo Regime nos Trópicos. Buscamos compreendê-las epistemologicamente com o intuito de explicar as características do acalorado debate historiográfico atual. Analisamos as bases de fundação da corrente "paulista", as principais teses que compõem a compreensão do passado colonial, a partir da consolidação das pesquisas de Fernando Novais. Explicamos alguns dos pontos que direcionaram a construção de sua obra A Crise do Antigo Sistema Colonial, tais como o marxismo/estruturalismo, a longa duração braudeliana etc. Demonstramos que, posteriormente à consolidação de sua obra, surgiram críticas, principalmente, depois da década de 90, a partir das teses de João Fragoso e Manolo Florentino, e em 2001 a criação do grupo Antigo Regime nos trópicos. Ressaltamos as influências que esse grupo sofreu (tais como a do historiador português Antônio Manuel Hespanha e do filósofo francês Foucault), os desafios historiográficos lançados por esse grupo e, sobretudo, mas, também os desenlaces advindos de sua tese, tais como a exclusão dos estudos referentes à escravidão. Atrelamos o desenvolvimento do grupo às críticas pós-modernas, ao 
neoliberalismo e à conjuntura econômica dos últimos anos. Nossa hipótese é a de que o surgimento do grupo "carioca" explica-se pelo contexto da década de 1990 e 2000, no qual procura-se entender os problemas brasileiros. Em conjunto com as propostas políticas adotadas, notadamente ligadas ao neoliberalismo, a tese é a de que os problemas do Brasil existiam devido a uma longa duração da desigualdade social, fruto do acúmulo interno de capitais, de maneira hierarquizada. Em suma, o problema não estava no capitalismo externo, como procurou explicar Novais e grande número de autores nas décadas de 1950, 60 e 70.

Abstract: This article takes up the historiographical bases of two Brazilian tendencies: Antigo Sistema Colonial and Antigo Regime nos Trópicos. We seek to understand them epistemologically in order to explain the characteristics of the current historiographical heated clash. We analyze the founding basis of the "Paulista" tendency, the main theses that compose the understanding of the colonial past, from the consolidation of the research of Fernando Novais. We explain some of the keywords that have directed the construction of his work "Crise do Antigo Sistema Colonial", such as Marxism/ structuralism, Braudelian long term, etc. We have shown that after the consolidation of his work, there were criticisms, especially after the 90s, from the thesis of João Fragoso and Manolo Florentino, and later, in 2001, with the creation of the group Antigo Regime nos trópicos. We emphasize the influences that this group suffered (such as Foucault and the Portuguese author António Manuel Hespanha), the historiographical challenges he launched and, above all, the challenges they must face (as the "exclusion" of slavery in their explanations). We connected the development of the group to post-modern criticism to neoliberalism and the economic situation of recent years. Our hypothesis is that the emergence of the group "carioca" is explained by the context of the 1990s and 2000s, which seeks to understand Brazilian problems in face of the policy proposals, neoliberalism, the thesis is that Brazil's problems exist because of a long-term social inequality, the result of internal capital accumulation, in a hierarchical manner. The problem was not in the external capitalism, tried to explain how Novais and large number of authors in the 50,60 and 70 .

Palavras-chave: Historiografia Colonial; história econômica; história política. 
Keywords: Colonial Historiography; economic history; political history.

\section{Introdução}

Existem dois modelos distintos de escrita da história sobre o Brasil colonial em vigência. ${ }^{1}$ Ressaltar as diferenças de ambas as narrativas constitui o objetivo primeiro deste artigo. Pretendemos diferenciá-los no tempo e no espaço de maneira a compreender as possíveis influências gerais da composição de seus escopos narrativos, seus métodos, seus assuntos privilegiados e escamoteados. Para tal intuito, destacamos alguns autores como representantes das linhas de pensamento de cada grupo, seja por estruturarem suas narrativas e "orientarem" uma gama de trabalhos que são norteadores da escrita da história atual, seja pelo poder simbólico que esses autores passaram a exercer no campo historiográfico, como coordenadores de cursos de pós-graduação, de importantes revistas historiográficas ou como organizadores dos principais livros sobre a temática.

Partimos, portanto, da concepção de que a operação historiográfica é compreendida dentro e fora dos textos, que "a operação histórica se refere à combinação de um lugar social, de práticas 'científicas' e de uma escrita. ${ }^{2}$. Michel de Certeau, em Escrita da História, nos deu elementos para pensar a "construção" do texto historiográfico como um fator que é determinado pelo lugar social. Em outros termos, na prática da escrita dos textos de história existem não-ditos subscritos, o peso da convenção da avaliação pelos pares e ainda a influência dos fomentos de pesquisa.

0 método de análise que aqui empregamos é o comparativo, pois, "na base de quase toda crítica inscreve-se um trabalho de comparação"3 Sendo assim, analisamos a

\footnotetext{
${ }^{1}$ Por razões didáticas, necessárias, optamos por tornar binária a explicação historiográfica, elegemos dois grupos distintos e conflitantes para explicar a situação atual do debate historiográfico no país: Antigo Sistema Colonial (ASC) e Antigo Regime nos Trópicos (ART). 0 primeiro tem um epicentro institucional em SP e o segundo no RJ. De antemão, adiantamos que a dicotomia didática não pode ser levada às últimas consequências, em outras palavras, seria radicalmente simplista acreditar que os diversos pesquisadores coloniais brasileiros estejam engessados a essa maneira binária de pensar, por isso, destacamos que há dois modelos que, em niveis internos, são bases explicativas para nossa história. Ocorre que um trabalho que pretenda mapear toda produção historiográfica está aquém de nossas aspirações. Temos plena convicção da plasticidade e impalpabilidade de algumas ideias por parte dos historiadores (consciente ou inconscientemente). É justamente por esse espaço existir, que precisamos categorizar e distinguir tais pensamentos. Embora não possamos afirmar que ASC e ART existam materialmente e que nem todos os historiadores estejam escrevendo em consonância com tais posições (ainda que haja uma pretensão desse controle). É notório, entretanto, que existem dois programas distintos e conflitantes sendo colocados em prática na produção historiográfica. Por isso, este texto pretende contribuir para a compreensão e explicação das referidas e imaginadas correntes interpretativas.

${ }^{2}$ CERTEAU, Michel de. A Escrita da História. Rio de Janeiro: Forense-Universitária, 1982. p. 65.

${ }^{3}$ BLOCH, Marc. Apologia da História ou ofício do historiador. 1997. p. 109. 
historiografia com os dois arcabouços teóricos selecionados acima, na medida em que se inscreve na ordem do dia uma pesquisa que explique o debate de maneira comparativa, levando em conta o lugar social desses intérpretes.

Os modelos demonstrados são: Antigo Sistema Colonial (ASC), de Fernando Novais, baseado em sua tese de doutoramento defendida em 1973, Portugal e Brasil na Crise do Antigo Sistema Colonial (1777 - 1808). ${ }^{4}$ E Antigo Regime nos Trópicos (ART) que deriva da obra organizada pelos autores João Fragoso e Maria de Fátima Gouvêa, Antigo Regime nos Trópicos: a dinâmica imperial portuguesa (séculos XVI-XVIII), publicada em 2001. ${ }^{5}$

Nossa intenção não é demonstrar todas as explicações que ambas as linhas historiográficas construíram ao longo do tempo, sobretudo no que se refere ao ASC, com ampla predominância na escrita desde a década de 1970. Também cabe lembrar que esses grupos não foram soberanos na escrita da história colonial, ou seja, não há evidência de um domínio completo no campo historiográfico brasileiro, visto que diversos pólos (a exemplo dos brasilianistas) surgiram com o passar dos anos. Os livros citados acima não podem ser concebidos como religiosos, sagrados ou manuais de pesquisa. Eles são expressões de modos distintos de praticar história. Podem existir obras que escapem aos domínios e às influências de tais livros no âmbito da história colonial, o que não nos coube analisar aqui. Por isso, este artigo tem essa limitação.

Outra limitação encontra-se na dificuldade que tivemos em tentar lançar luz sobre as posições políticas de alguns dos autores referenciados. Somente pudemos apontar com certeza a posição política que tinha Caio Prado Júnior, justamente, por ele ter sido político e não historiador. Nos interessaria perceber, sobretudo, a posição política de integrantes do grupo Antigo Regime nos Trópicos. Entretanto, o que parece marcar seus trabalhos não é uma proposta política, mas, antes, uma interpretação histórica destituída de expectativa para o futuro, diferentemente dos aspectos que marcam os trabalhos de Caio Prado. Poderíamos trabalhar com entrevistas a respeito da posição política de vários autores; não obstante, ao que tudo indica, as suas propostas políticas (se existem) não direcionam seus textos de maneira definitiva. Outra opção seria mapear as suas posições partidárias, todavia, perante a grande diversidade de pensamentos a respeito da atual conjuntura

\footnotetext{
${ }^{4}$ NOVAIS, Fernando A. Portugal e Brasil na crise do Antigo Sistema Colonial (1777 - 1808). São Paulo: Hucitec, 1979.

${ }^{5}$ FRAGOSO, João; BICALHO, Maria Fernanda e GOUVÊA, Maria de Fátima (org.). 0 Antigo Regime nos trópicos: A dinâmica imperial portuguesa (século XVI-XVIII). 2a edição. Rio de Janeiro: Civilização Brasileira, 2010. 
política, sobretudo, depois da divisão entre alguns historiadores no processo de Impeachment da presidente Dilma Rousseff, quando uma parte passou a apoiar o processo e a outra a criticar. ${ }^{6}$ Portanto, torna-se mais sensato considerarmos os grupos como agentes dentro de contextos históricos, embebidos por um pensamento coletivo, resultantes de lugares sociais e não cair numa barafunda, norteada por uma pesquisa que abarque os pensamentos e escolhas individuais.

Em síntese, este artigo tem duas intenções: primeira, explanar de maneira esquemática vertentes da historiografia nacional sobre a História Colonial do Brasil, reunindo argumentos que, por conta da limitação do gênero em que se encontram desenvolvidos, podem ter resvalado em algum grau de superficialidade. Conscientes disso, procuramos delimitar uma linha de raciocínio e segui-la. A segunda, levantar questões e apontar alguns caminhos tomados pelos historiadores, buscando explicar algumas escolhas que, sob o nosso ponto de vista, faltavam ser sintetizadas em um artigo.

Nossa hipótese a respeito da diferença interpretativa da história do Brasil colonial por parte desses grupos se situa dentro de uma problemática na qual se atrelam ideologias e momentos distintos da história. A abordagem ASC constitui-se em uma concepção materialista da história, que o grupo ART pretendeu superar, e mesmo destruir, com a proposta de um "novo método". Mais do que romper com o materialismo histórico, o grupo buscou romper com o materialismo derivado da tese de Fernando Novais e com o debate historiográfico que esse materialismo articulou, como fica evidente nas obras combativas e revisionistas do ART. Toda obra deste grupo é de combate, e se situa em constante diálogo com a do grupo ASC. Observemos o que dizem João Fragoso e Maria de Fátima Gouvêa na introdução de Na Trama das Redes, publicado em 2010, sobre suas propostas de 2001, no livro Antigo Regime nos Trópicos.

$\mathrm{Na}$ época, tal trabalho surgiu com a pretensão de contribuir para as pesquisas de ponta na área de conhecimento então chamada de história colonial brasileira. Na verdade, pretendia-se ultrapassar - sem negar a importância - o debate historiográfico que trata

\footnotetext{
${ }^{6}$ Observe o Grupo Historiadores pela democracia, organizados por Hebe Mattos, do qual João Fragoso faz parte. Outros autores do grupo ART se posicionaram a favor do Impeachment. Muito do posicionamento sobre esse processo está ligado á posição política dos autores. Observamos, assim, diferente formas de pensar a política e o Brasil, mesmo dentro do grupo. Dessa forma, não podemos atribuir ao grupo uma

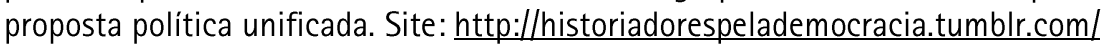


da dependência externa versus a excessiva ênfase no caráter único e singular da sociedade colonial-escravista. ${ }^{7}$

Portanto, nos pilares de seus textos, desde o início, existe como mote a expectativa de superar o modo de escrever a história sob a perspectiva do grupo ASC, na medida em que, por exemplo, a primeira nota (crítica) de rodapé refere-se a autores como Caio Prado Júnior, Fernando Novais e Ciro Flamarion Cardoso, que figuravam no debate historiográfico até então. ${ }^{8}$ Segundo ainda os organizadores, a premissa inicial foi colocada em segundo plano perante os resultados posteriores da publicação do livro Antigo Regime nos Trópicos. Em outros termos, eles tinham construído um modelo de escrita histórica completamente diferente daquele que estava preso ao debate da dinâmica interna versus exportação. 0 que falta a se fazer é matizar as diferenças entre os modos de se conceber as narrativas histórias e traçar as linhas que diferem os modelos analíticos. Para isso, fizemos uma reconstrução teórica do ASC para então mostrarmos as diferenças entre oS grupos.

\title{
Epistemologia do ASC: Paradigma "Sentido Da Colonização"
}

De muitas maneiras pode ser feita a narrativa desse debate. Optamos, entretanto, por iniciar a exposição demonstrando - resumidamente - a constituição do ASC para depois somente explicar a evolução histórica do grupo ART. A composição da obra de Novais, elaborador da tese que principiou a vertente interpretativa do ASC, tem dois grandes pilares: as obras de Caio Prado Júnior e Eric Williams. Comecemos pelo primeiro:

\begin{abstract}
Não sofremos nenhuma descontinuidade no decorrer da história da colônia (...) Se vamos à essência da nossa formação, veremos que na realidade nos constituimos para fornecer açúcar, tabaco, alguns outros gêneros; mais tarde ouro e diamantes; depois, algodão, e em seguida café, para o comércio europeu (...) Este início, cujo caráter se manterá dominante através dos três séculos que vão até o momento em que ora abordamos a história brasileira, se agravará profunda e totalmente nas feições e na vida do pais(... $)^{9}$
\end{abstract}

As frases acima, do político Caio Prado Júnior, revelam a essência do seu pensamento histórico em observância a uma continuidade histórica do modo como se

\footnotetext{
${ }^{7}$ FRAGOSO, J. \& GOUVÊA, M. de Fátima. Na Trama das Redes. Política e negócio no império português, séculos XVI-XVIII. Rio de Janeiro: Record, 2010. P. 13

${ }^{8}$ A discussão, iniciada na década de 1970 girava em torno da concepção de haver ou não uma dinâmica interna em detrimento das exportações como epicentro da colonização. A proposta, portanto, era superar esse debate.

${ }^{9}$ PRADO JÚNIOR, Caio. Formação do Brasil Contemporâneo: Colônia. 24a edição. São Paulo: Brasiliense, 1996. P. 8 
constituiu o seu Brasil contemporâneo, em que se percebe a saliente preocupação do autor com o momento em que vivia, o que, aliás, é parte integrante de toda a sua obra. Observa-se que suas conjecturas se direcionam no sentido de explicar o presente e não o passado. Cabe ainda ressaltar, que não foi uma exclusividade do autor a iniciativa de procurar no passado colonial a explicação para o seu presente. Também o fizeram Sérgio Buarque de Holanda, ${ }^{10}$ Gilberto Freyre, ${ }^{11}$ Roberto Simonsen, ${ }^{12}$ Nelson Werneck Sodré, ${ }^{13}$ entre outros. Entretanto, nos interessa analisar mais de perto os problemas históricos levantados por Caio Prado Júnior, de viés econômico, relacionados à sua concepção materialista, pela qual o autor procurava explicar, historicamente, o atraso econômico do Brasil. Para além de uma explicação, sua obra constituiu-se em uma proposta política para o país, ${ }_{1}^{14}$ marcadamente conservadora.

0 que significa a recusa da "tese feudal" e a sua substituição pela "tese capitalista" para o Brasil desde as suas origens? Os defensores da tese feudal afirmarão que a tese capitalista provoca um recuo, uma concessão ao passado brasileiro. É uma tese "atrasada", "reacionária", que privilegia a continuidade do Brasil colonial em prejuízo da mudança socialista. Caio Prado expressaria um ponto de vista reacionário e atrasado e representaria um recuo, uma regressão na consciência revolucionária socialista. Suas teses protegem a grande propriedade latifundiária da redistribuição. Não seria pelo fato de sua família e ele próprio serem grandes proprietários de terras? ${ }^{15}$

No âmbito da formação do campo historiográfico proposto pelo autor prevalece uma análise voltada para uma proposta política que observava no passado a permanência da grande propriedade em detrimento dos minifúndios. ${ }^{16}$ Tal concepção privilegiava 0 aproveitamento das plantations escravistas em sua essência. Ao debater com o partido PCB e sua interpretação etapista da história, ele estaria postergando uma revolução.

\footnotetext{
${ }^{10}$ HOLANDA, Sérgio Buarque de. Raizes do Brasil. Primeira edição de 1936

${ }^{11}$ FREYRE, Gilberto. Casa Grande e Senzala. Formação da Familia Brasileira sob o regime patriarcal. 18a edição brasileira. Rio de Janeiro: José Olympio editora, 1977.

${ }^{12}$ SIMONSEN, Roberto. História Econômica do Brasil. 3 ed. Editora do Senado Federal: 2005

${ }^{13}$ SODRÉ, Nelson Werneck. Formação histórica do Brasil. São Paulo: Brasiliense, 1962.

${ }^{14}$ MENDES, Claudinei. M. M. Politica e história em Caio Prado Júnior. São Luis: $1^{1}$ ed. UEMA, 2008.

${ }^{15}$ REIS, José Carlos. As identidades do Brasil: de Varnhagen a FHC. 8.ed. Rio de Janeiro: Ed. FGV, 2006

${ }^{16}$ FERLINI, Vera Lúcia A. Terra, trabalho e poder. São Paulo: Brasiliense, 1988; Idem. Açúcar e colonização. São Paulo: Alameda, 2010. 
Caio Prado Júnior era marxista de formação, mas não ortodoxo e categórico em sua interpretação, aplicou de maneira fluida o materialismo histórico ${ }^{17}$ em sua narrativa ${ }^{18}$, e observou negativamente o passado, ou a continuidade colonial. Esta seria a perene necessidade de o país exportar para o mercado externo sua produção, sendo uma plataforma de exportação. Baseado nessa premissa, ele explicaria o fato de o Brasil da década de 1930 ainda não estar plenamente industrializado e ser necessariamente rural, monocultor e latifundiário. Por isso, lança sua proposta de desenvolvimento não pelo viés da revolução socialista, mas, pela construção de uma economia nacional.

No entender de Caio Prado Júnior, o Brasil deveria superar a sua longa duração histórica para se desenvolver. Com efeito, assombrava a intelectualidade da época o papel econômico que país vinha desempenhando: atender às necessidades econômicas externas. Ao estudar a Colônia, o autor tinha por finalidade distinguir a história do país, afirmando que o grande problema ligado ao sentido econômico da colonização foi não ter desenvolvido uma economia nacional. Prevalecia o que ele chamou de economia colonial. Em outros termos, por sua produção ter se voltado quase que exclusivamente para 0 mercado europeu, inibiu-se a evolução interna da economia brasileira. Portanto, o sentido da colonização ainda se fazia presente, já que o país não havia se industrializado. A necessidade do Brasil era criar as condições para a evolução de um mercado interno e depois se industrializar, rompendo definitivamente com o sentido da colonização. Caio Prado não teve como intenção construir um texto historiográfico, antes, procurou construir na história uma proposta política fundamentada na Colônia. Seu texto, com efeito, se tornou um dos mais influentes da historiografia nacional e chegou a criar uma escola historiográfica derivada de sua interpretação. 0 seu materialismo histórico o fez observar o passado colonial de maneira negativa e colocar no presente o peso dessa abordagem, ao imaginar uma Colônia onde prevalecia (ou só existia) latifúndio, trabalho e exportação. Em última análise, a Colônia (presente no seu Brasil contemporâneo) era o símbolo máximo do atraso.

\footnotetext{
170 autor, embora marxista, teve a sutileza de romper com a tradicional linha analítica da escola historiográfica que interpretava não tentando forcejar uma espécie de feudalismo nos trópicos. Como, de certo modo, o fizeram outros autores ligados ao Partido Comunista. Caio Prado Júnior diversas vezes se mostrou contrário à ideia de que o Brasil deveria passar pelas cinco etapas da história, como o fizeram SODRÉ, Op. cit. e IGLÉSIAS Op. cit., p. 202.

${ }^{18}$ IGLÉSIAS, Francisco. Historiadores do Brasil. Rio de Janeiro/ Belo Horizonte: UFMG/Nova Fronteira, 2000. 


\section{Eric Williams e o Comércio Colonial}

0 escritor de Trinidad e Tobago, Eric Williams pode ser considerado um dos maiores escritores do século $X X$ sobre o papel desempenhado pela escravidão moderna na fundamentação do mundo capitalista moderno. A partir de seu livro, Capitalismo e Escravidão $0^{19}$ ele estabelece um dos principais pilares do estudo referente ao assunto. Rafael de Bivar Marquese ${ }^{20}$ nos deu elementos para compreender as influências desse autor na historiografia brasileira, ao demonstrar uma grande similitude entre as obras de Caio Prado Júnior e Eric Williams, mesmo sem que os autores - ao escreverem suas obras principais - tenham lido um ao outro. 0 primeiro impacto desse autor no Brasil foi no contexto da escola sociológica da USP (com Roger Bastide e Florestan Fernandes), que na década de 1950 buscou romper com a noção brasileira de democracia racial. Depois disso, exerceu também influência sobre a escola Cepalina e forneceu as bases para os estudos da teoria da dependência, cujo melhor exemplo seria a obra de Fernando Henrique Cardoso. Mas, foi por meio de Fernando Novais e Emilia Viotti da Costa que seu trabalho foi difundido. ${ }^{21}$

A tese de Williams, no que se refere à nossa problemática, resume-se nos seguintes motes: em primeiro lugar, o autor defende que a escravidão e o tráfico de escravos foram motores para o desenvolvimento industrial inglês. 0 comércio triangular deu estímulos ao incremento comercial daquele país de três maneiras: (1) pelo capital produzido na troca de escravos na África; (2) com as plantations escravistas; (3) mediante a necessidade que havia de políticas mercantilistas.22 Por meio do capital investido no tráfico de escravos, a sociedade inglesa, em todos os seus planos, passou a conceber o tráfico como elemento importante de sua economia "Antes de 1783, porém, todas as classes da sociedade inglesa sustentavam o tráfico negreiro. A monarquia, o Governo, a lgreja, a opinião pública em geral, apoiavam o tráfico de escravos". ${ }^{23}$ Essa condição implicou numa política de governo para sustentar o trato, ou seja, a valorização de uma política mercantilista pela qual se

\footnotetext{
${ }^{19}$ Seu trabalho de doutoramento foi na Inglaterra (Oxford): The Economic Aspect of the Abolition of West Indian Slave Trad and Slavery (1938). WILLIAMS, Eric. Capitalism and slavery. The University of North Carolina Press, 1994 [1944].

${ }^{20}$ MARQUESE, Rafael. Capitalismo \&t escravidão e a historiografia sobre a escravidão nas Américas. Estudos. vol.26 no.75 São Paulo, 2012

${ }^{21} \mathrm{Em}$ que pese, o autor ainda coloca as críticas feitas à obra de Williams (as brasileiras, por meio de Ciro Flamarion Cardoso). E demonstra as variações históricas referente ao uso de sua tese nas obras.

22 MATHIANS, Carlos Leonardo Kelmer. A tese de Williams e o Antigo Sistema Colonial: notas sobre um debate clássico. História e historiografia. Ouro Preto, n. 11, abril, 2013. pp. 190-209. P. 193.

${ }^{23}$ WILLIAMS, Op. cit. p. 44 
exercia a exclusividade legal da política comercial com as Colônias proibindo que elas comercializassem com outros países. Nesse aspecto, fundamenta-se o comércio triangular entre Inglaterra - Caribe - África. Tal imposição forcejou as Colônias a criarem um sistema escravista e monocultor. Arremata no ponto em que entende o movimento abolicionista como fruto de um desinteresse pela mão de obra escrava como um aspecto característico do capitalismo, o que tornou-se um entrave real para a exportação da indústria. Por conseguinte, a sociedade entendeu que a mão de obra escrava entravava 0 desenvolvimento do livre mercado.

\section{A escola "Antigo Sistema Colonial"}

Fernando Novais, em seu livro Portugal e Brasil da crise do Antigo Sistema Colonial, parte das teorias de Caio Prado Júnior e Eric Williams para desenvolver sua hipótese histórica sobre o Brasil Colônia. Notamos que diferentemente de Prado Júnior, e de modo similar a Eric Williams, Novais é um historiador de ofício e sua tese se diferencia do livro Formação do Brasil Contemporâneo, que é um ensaio e se aproxima de Capitalismo e escravidão, também tese acadêmica. Muito embora, Williams tenha sido o Primeiro Ministro de Trinidad y Tobago e tenha participado politicamente dos movimentos de colonização.

Novais assume o papel de discípulo de Prado Júnior e se propõe aprofundar a sua interpretação de um prisma acadêmico. Defendida na USP, na década de 1970, sua tese teve um grande impacto nacional e criou uma escola historiográfica em torno da interpretação do Brasil Colônia como fruto de um sistema colonial.

Muito bem elaborado do ponto de vista teórico-metodológico, o texto de Novais explica o Brasil dentro do quadro do desenvolvimento do capitalismo europeu. Resumidamente, a colonização do novo mundo foi para ele uma etapa muito importante da formação do capitalismo europeu. A colonização europeia teve sentido histórico exercendo a função de uma alavanca para a acumulação primitiva de capital europeu. Neste ponto reside o emprego da tese de Caio Prado Júnior sobre o sentido da colonização, de um ângulo de vista invertido, do velho continente. Nessa abordagem, 0 materialismo histórico redimensiona a tese do autor de A crise do Antigo Sistema Colonial.

Não obstante, Novais tinha como questão principal tratar da evolução histórica do capitalismo (assim como Williams) e, Prado Júnior, do desenvolvimento econômico do 
Brasil. Para Novais, as Colônias, por meio do exclusivo comercial, eram exploradas economicamente pelas potências europeias em ascensão capitalista. Assim, explicar-se-ia, dentro do sistema colonial, a tese de sentido da colonização brasileira, ou seja, a sua relação com o mercado externo ter contribuído para inibir o interno. Sendo assim, 0 Estado, fortemente centralizado, tinha o poder de dominar as relações ultramarinas com a finalidade de realizar uma exploração parasitária em suas Colônias, como também é marcante em Capitalismo e Escravidão.

Nesta fase intermediária, em que a expansão das relações mercantis promovia a superação da economia dominial e a transição de regime servil assalariado, o capital comercial comandou as transformações econômicas mas a burguesia mercantil encontrava obstáculos de toda ordem para manter o ritmo de expansão das atividades e ascensão social; daí, no plano econômico, a necessidade de apoios externos - as economias coloniais - para fomentar acumulação, e no nível político a centralização do poder para unificar o mercado nacional e mobilizar recursos para o desenvolvimento. Nesse sentido, o Antigo Regime Político - essa estranha e aparente projeção do poder para fora da sociedade - representou a fórmula de a burguesia mercantil assegurar-se das condições para garantir sua própria ascensão e criar o quadro institucional do desenvolvimento do capitalismo comercial. ${ }^{24}$

Apesar de haver uma distância entre as ideias de Caio Prado Júnior e Fernando Novais costuma-se, equivocamente, conceber as teses dos autores como idênticas. ${ }^{25}$ Todavia, deve-se distinguir suas explicações históricas, na medida em que, os conceitos de pacto colonial e sistema colonial foram perscrutados por Novais, e não por Caio Prado. Este último preocupou-se com o desenvolvimento do Brasil, o outro, além disso, teve como objetivo o plano geral do desenvolvimento capitalista. Desse ponto de vista, a tese Sistema colonial pretendeu ser uma extensão explicativa do sentido da colonização. Assim, deve-se perceber que a tese de Novais é uma interpretação histórica derivada da tese política de Caio Prado Júnior e não, propriamente, a sua explicação, sendo interpretações

\footnotetext{
${ }^{24}$ NOVAIS, Fernando. Op. Cit. p. 66-67

${ }^{25}$ Nos referimos ao Grupo ART. Tomemos por exemplo a introdução do livro: FRAGOSO, João Luis Ribeiro Fragoso. Homens de Grossa Aventura: acumulação e hierarquia na praça mercantil do Rio de Janeiro (17901830). Rio de Janeiro: Civilização Brasileira, 1998. 
diferentes. É preciso não perder de vista que foi Novais quem propôs uma interpretação da ideia do sentido da colonização. ${ }^{26}$

Se combinarmos, agora, esta formulação - 0 caráter comercial dos empreendimentos coloniais da época moderna - com as considerações anteriormente feitas sobre o Antigo Regime - etapa intermediária entre a desintegração do feudalismo e a constituição do capitalismo industrial - a idéia de um "sentido" da colonização atingirá seu pleno desenvolvimento. ${ }^{27}$

Também vista em Formação do Brasil Contemporâneo, a ideia de exploração colonial constitui um fator fundamental na tese de Novais, pois é o mote explicativo dentro do quadro teórico do Antigo Sistema Colonial. 0 mercantilismo teria sido o vetor que estruturou a sociedade do Antigo Regime com a finalidade de alavancar a acumulação primitiva do capital europeu, sendo fundamentalmente comercial. Em última análise, se conclui que, embora houvesse alguns tipos de existência que se sobressaíam à ordem geral (como o comércio de cachaça e de farinha de mandioca), segundo o autor, tudo estava dentro do quadro do sistema voltado à acumulação:

Em suma, licenças, concessões, contrabando, parecem-nos fenômenos que se situam mais na área de disputa entre as várias metrópoles europeias para se apropriarem das vantagens da exploração colonial - que funciona no conjunto do sistema, isto é, nas relações da economia central europeia com as economias coloniais periféricas. Não atingem, portanto, a essência do sistema de exploração colonial. ${ }^{28}$

Desse modo, a tese de Novais compõe um sistema fechado que buscou explanar o papel histórico do Brasil na passagem do Feudalismo para o Capitalismo europeu. Por conta disso, sua análise é global e tende a ignorar os fatores locais, como contrabandos, desenvolvimento interno e acumulação endógena que constituem fatores de ordem secundária. ${ }^{29} \mathrm{Em}$ que pese essa máxima, não era sua intenção explicar as variantes internas, mas tentar compreender o papel do Brasil no desenvolvimento do capitalismo. Não podemos observar essa explicação como uma deficiência das suas obras, pois, os autores devem ser criticados dentro de suas propostas e não ser cobrados por aquilo que não se propuseram a fazer, sobretudo, anos após o contexto de sua produção

\footnotetext{
${ }^{26}$ MENDES, Claudinei M. Um estudo sobre a relação entre Caio Prado Júnior e Fernando A. Novais. Acta Scientiarum. Human and Social Sciences. Maringá, v. 35, n. 2, p. 189-199, July-Dec., 2013

${ }^{27}$ NOVAIS, Fernando. Op. Cit. p. 30

${ }^{28}$ Ibidem. p. 91.

${ }^{29}$ Abaixo esse tópico é desenvolvido como critica do ART.

Almanack. Guarulhos, n.15, p. $245-293$ 
historiográfica, desconsiderando as tendências, as preocupações, os pares, as condições daquele momento. Ao tentar elaborar uma crítica devemos compreender 0 ambiente que 0 autor escreveu e, acima de tudo, sua proposta e preocupação - política ou acadêmica.

Da análise de Caio Prado e Fernando Novais, de fato, deriva a noção dicotômica existente na relação entre Metrópole/Colônia. Sobretudo em Novais, verifica-se uma acentuada dicotomia desencadeada pela exploração colonial. Ele demonstra uma relação conflituosa no processo de colonização que desencadeou o declínio do sistema colonial, momento no qual se tornaram mais latentes as diferenças ideológicas entre Metrópole e Colônia. A Crise do Antigo Sistema Colonial decorre, portanto, de uma tomada de consciência dos colonos em relação à posição de explorados que, no final do século XVIII, permitiu romper as amarras mentais que subordinavam a Colônia à Metrópole.

Crise no sistema colonial é, portanto, aqui entendida como o conjunto de tendências políticas e econômicas que forcejaram no sentido de distender ou mesmo desatar os laços de subordinação que vinculam as colônias ultramarinas às metrópoles europeias. Elas se manifestam no bojo da crise do Antigo Regime, variando e reajustando-se ao ritmo daquela transformação. ${ }^{30}$

Para Novais, a relação entre Metrópole e Colônia é vista de forma antagônica, entre opressor e oprimido, tendo-se em vista que procura explicar a colonização como um fator de exploração europeia das riquezas tropicais. Essa relação figurava no comércio e se fazia presente no seu Brasil contemporâneo, e ainda mais no de Caio Prado Júnior, pois, segundo os autores, não tinha sido desfeita com a independência política de 1822.

Considerando, portanto, o ponto de vista dos autores paulistas, pode-se dizer que há uma relação binária e conflitante entre Brasil e Portugal, reafirmada de forma mais categórica em Novais. 0 sentido da colonização, dessa maneira, explica-se pela divisão de interesses entre a Metrópole e a Colônia, haja vista que produzir exclusivamente para fora (para a Europa, como alavanca para o capitalismo), implicava em uma desvantagem econômica, no âmago dos pensamentos dependistas. Numa análise mais categórica e esquemática, o Sistema Colonial, por sua vez, elimina qualquer possibilidade dos colonos (do ponto de vista global) se sobressaírem aos metropolitanos, pois, tiveram a função histórica de servir, assim como a Colônia, de alavanca para o desenvolvimento capitalista europeu. Qualquer fator externo a essa máxima era um elemento desviante da lógica

${ }^{30}$ NOVAIS, Fernando. Op. Cit., p. 13. 
estabelecida, incomum e esporádico. Da conscientização dessa relação desigual, advinda do desenvolvimento econômico das Colônias, emergiu a falência interna do sistema, marcadamente desigual. 0 final do século XVIII foi o momento dessa mudança de pensamento e o XIX, a cisão final.

Ao analisar a obra de Novais e de seus discípulos, alguns pontos são bem caracteristicos no que se refere à influência exercida pela obra de Eric Williams. 0 comércio triangular (base de sustentação de Williams) foi o elemento central da tese de Fernando Novais, no que se refere à relação comercial que o Brasil mantinha com a África, sendo a explicação para o trato negreiro. 0 tráfico de escravos teria a função estruturadora da produção colonial, primeiro do açúcar e depois do ouro. Assim, como teria ocorrido com a Inglaterra, a politica mercantilista fornecera bases legais para os ganhos advindos da exploração. Em que pese a diferença, Portugal manteve seu antigo regime intacto enquanto a Inglaterra orientou a exploração para a nascente burguesia. Entretanto, a própria relação diplomática de Portugal e Inglaterra, a partir dos tratados posteriores a 1640, consubstancia a proximidade e a intenção dos ingleses em desenvolver sua indústria a partir de uma política comercial externa que tencionava o lucro. Novais não somente concorda com a tese de Williams, como também a endossa demonstrando a importância do comércio triangular.

Para Novais, assim como para Eric Williams, as plantations monocultoras juncadas pelo trabalho escravo africano tiveram como função sustentar o acúmulo de capital europeu e, por consequência, desenvolveu a burguesia metropolitana. A criação do Pacto Colonial, para Novais, foi pré-requisito para a industrialização europeia e para 0 desenvolvimento histórico do capitalismo; as Colônias foram condição sine qua non para desenvolver as economias capitalistas europeia.

\section{Primeiras críticas: a Brecha Camponesa}

Na década de 1970, as interpretações de Caio Prado Júnior e Fernando Novais receberam as primeiras criticas de alguns autores, com destaque para Ciro Flamarion Cardoso $^{31}$ e Jacob Gorender. ${ }^{32}$

\footnotetext{
${ }^{31}$ CARDOSO, Ciro Flamarion S. Agricultura, escravidão e capitalismo. Petrópolis: Editora Vozes Ltda., 1979.

32 GORENDER, J. 0 escravismo colonial. São Paulo: Ática, 1978. 
Cardoso, ao observar as relações de trabalho na América, encontrou algumas dissonâncias nas teses sentido da colonização e sistema colonial. Como mostrado acima, as interpretações advindas do paradigma pradiano tendem a estudar as relações de produção voltadas somente para a exportação; por isso mesmo, os estudos do ASC se orientaram para a produção com base no trabalho escravo, primeiro voltado para o açúcar, depois para o ouro e o café. Nesse aspecto reside a crítica do autor carioca. Os pesquisadores que abordavam o assunto, entendendo o período como fruto exclusivo das produções externas, distorceram a história "obcecada pela plantation monocultora e exportadora". A crítica de Cardoso (sua contribuição historiográfica) se encontra na construção de uma história para além das relações interna/externa, norteada por uma dinâmica interna que se baseava naquilo que chamou de brecha camponesa. Ao estudar a crítica construída por Ciro Flamarion, Mendes conclui:

Ao definir as atividades econômicas autônomas dos escravos que escapavam do sistema de plantation como brecha camponesa, Cardoso pretendeu valorizar o que denominou de variáveis internas. Sua intenção foi mostrar que, na colônia, existiam atividades produtivas que, escapando às injunções externas, davam à sociedade colonial uma estrutura que não era explicada somente por sua ligação com o mercado mundial. Chegou a considerar a brecha como uma atividade universal no escravismo americano, portanto, um fato estrutural da escravidão colonial. ${ }^{33}$

De fato, havia uma acentuada dinâmica interna que escapava às interpretações dos autores paulistas e seus discípulos. Mas, ao buscar contraporem-se a essas explanações, os estudos baseados na obra de Ciro Flamarion, em algum momento, passaram a acentuar em demasia sua explicação, transformando-a em caráter universal da produção colonial e, por isso, conceberam a brecha camponesa ${ }^{34}$ como um fator estruturador da sociedade da Colônia. Mas, o que compete indagar é: as interpretações fundamentadas no seio da brecha camponesa, teoricamente, superaram o estudo de Caio Prado Júnior e Fernando Novais? Ao admitir que existia, para além de uma produção voltada para o mercado externo, uma produção interna, o conceito de brecha camponesa superou e substituiu o modo de se conceber a história da Colônia estabelecido até então? Diretamente, devido à

\footnotetext{
${ }^{33}$ MENDES, C. M. M. Politica e história em Caio Prado Júnior. São Luis: 1a ed. UEMA, 2008, P. 57. ${ }^{34}$ CARDOSO, Ciro Flamarion S. A brecha camponesa no sistema escravista. In: escravidão e capitalismo. Petrópolis: Vozes, 1979, p. 133-154. 
brecha camponesa, o sentido da colonização e o sistema colonial deixaram de servir como modelos explicativos de história?

As interpretações que procuraram valorizar a dinâmica interna da Colônia foram tão somente criadas dentro do circulo interpretativo de Caio Prado Júnior e Fernando Novais. 0 resultado final das críticas de Ciro Flamarion Cardoso foi o incremento do quadro interpretativo do autor de Formação do Brasil Contemporâneo de elementos não tratados por este devido a sua obsessão pela plantation monocultora. ${ }^{35}$ Entendemos como uma sofisticação do entendimento da história do Brasil colonial e não uma destruição ou superação da tese vigente.

Acerca da brecha camponesa, se antes apenas se observava o mercado externo na relação colonial, com o desenvolvimento equivocado de sua interpretação, passou-se apenas a conceber as relações internas da produção. Em resumo, o autor não chegou a discordar profundamente de Caio Prado, mas sim embutiu um valor nas variáveis internas de modo a atrelar historicidade às relações locais da colonização. ${ }^{36}$ Acerca de Caio Prado Júnior, ressaltamos que ele não tinha a intenção de observar as relações internas de produção. Sua preocupação era com o problema de seu Brasil Contemporâneo desindustrializado. Por isso, encontrou na Colônia o sentido do problema econômico de sua época, a tendência história, caracterizada como sentido da colonização, de produzir gêneros primários e exportar mercadorias para a Europa. Nesse caso, não tinha porque 0 autor estudar a dinâmica interna. Concluiu $\operatorname{Mendes}^{37}$ que 0 autor paulista estava comprometido politicamente com o seu tempo, fruto de um debate pela industrialização do país. Fernando Novais, ao pretender aprofundar-se no estudo sobre o sentido da colonização não superou Caio Prado Júnior porque se manteve dentro do seu quadro interpretativo, mesmo construindo um trabalho historiográfico diferente do ponto de vista histórico-metodológico. ${ }^{38}$

Ainda sobre Novais e sua tese, mais alguns pontos devem ser colocados em questão. Primeiro, devemos destacar que a análise do autor pauta-se dentro do quadro interpretativo marxista. Seu trabalho se pauta no estruturalismo, num momento crítico da guerra fria, e, portanto, de crítica profunda ao capitalismo, em que a esperança de uma

\footnotetext{
${ }^{35}$ MENDES, C. M. M. Op. cit., p. 59.

${ }^{36}$ Ibidem.

37 Loc cit.

${ }^{38}$ Loc cit

Almanack. Guarulhos, n.15, p. $245-293$
} 
proposta política do comunismo ainda figurava. Portanto, o trabalho de Novais é profundamente enraizado na segurança teórica dos estruturalistas. Seu pensamento é, de maneira lógica, embora as críticas muitas vezes ignorem isso, ligado aos homens de seu tempo.

Em 1965 Novais viaja à Europa e conversa com Fernand Braudel que, exatamente nesse momento produz sua obra Civilização Material Economia e Capitalismo, cuja principal preocupação é tão somente explicar o surgimento do Capitalismo, dentro dos seus três tempos históricos e de uma proposta - ao seu modo - estrutural da história, e recebe certa influência do autor francês. Mesmo Novais não citando Civilização material, economia e capitalismo em seu trabalho principal, percebemos que tem preocupações similares às de Braudel e, possivelmente, tenha sido influenciado por ele na construção de seu texto. ${ }^{39} \quad$ Um grande rol de autores desse contexto explica o surgimento e desenvolvimento do capitalismo do ponto de vista estrutural (marxista e não marxista): Eric Hobsbawm; ${ }^{40}$ Immanuel Wallerstein; ${ }^{41}$ Fernand Braude; ${ }^{42}$ Vitorino de Magalhães Godinho, ${ }^{43}$ entre outros. Podemos dizer que a colonização, para todos esses autores de variadas correntes historiográficas, é fruto do surgimento do capitalismo e, acima de tudo, tem como função servir como alavanca para o seu próprio desenvolvimento, termo que apenas Novais utilizou, mas que toda uma época entendeu assim. Em outras palavras, a Colônia teve uma função esquemática no âmbito do desenvolvimento do capitalismo e essa máxima serve de base para as análises de economistas, historiadores e sociólogos.

Contudo, principalmente no início da década de 1990, os rumos historiográficos do debate sobre a colonização brasileira, e mesmo mundial, começaram a mudar significativamente. Parte das explicações dessas mudanças deriva da conjuntura posterior à destituição da expectativa do comunismo, com o fracasso da URSS e a queda simbólica do Muro de Berlim. 0 neoliberalismo venceu como doutrina de governo. Com isso, demonstrou ao mundo ser a única maneira possivel de governo naquele momento, se

\footnotetext{
${ }^{39}$ Fernando Novais: Braudel e a missão francesa In: Estud. av. vol.8 no.22 São Paulo, 1994.

${ }^{40}$ HOBSBAWM, Eric. The General Crisis of the European Economy in the 17 th Century. Past \& Present, $n^{0} 5$. 1951. pp. 33-53.

${ }^{41}$ Wallerstein Immanuel. Y a-t-il une crise du XVIle siècle ?. In: Annales. Économies, Sociétés, Civilisations. 34e année, N. 1, 1979. pp. 126-144

${ }^{42}$ BRAUDEL, Fernand. Civilização material, economia e capitalismo: séculos XV - XVIII. Vol. 3. 0 tempo do mundo. Trad. Telma Costa. 2a Ed. São Paulo: Editora WMF Martins Fontes, 2009.

${ }^{43}$ GODINHO, Vitorino de Magalhães. Os Descobrimentos e a economia Mundial. Vol. 1. 2a edição. Lisboa: Editorial Presença, 1971. 
expandindo por várias partes do planeta. Junto a isso, os países do 0cidente, e o Brasil também, se entregaram ao viés neoliberal. Derivada desse mundo de dissoluções teóricas, correntes pós-modernas passaram a dirigir parte dos estudos historiográficos brasileiros. Acreditamos que esses dois fatores ajudam a explicar o surgimento e desenvolvimento do ART. Nos foquemos, entretanto, nesse momento no Pós-modernismo, conceito tão impreciso quanto sua essência teórica, ou ateórica.

\section{Pós-Modernismo}

0 campo historiográfico sofreu no século passado movimentos relevantes que culminaram na tentativa de superação do pensamento lluminista, em que a razão caracteriza-se como o centro das elucubrações. Ainda no século XIX, Nietzsche faz as primeiras críticas acerca das certezas de uma sociedade que tinha a crença na evolução, no progresso, a partir da razão e da ciência. A Escola Metódica Alemã, o Positivismo de Augusto Comte, e mesmo o Materialismo Histórico derivado da interpretação de Karl Marx, estavam soterrados pela crença inabalável na verdade. Mesmo sendo crítico da razão, Kant esteve ligado a esse pensamento racionalista e iluminista. ${ }^{44}$

Com a crítica feita pelos historiadores dos Annales aos historicistas (ditos positivistas) franceses ocorre uma tentativa de rompimento com essas certezas que existiam no bojo da historiografia e emanavam da filosofia burguesa. Tanto os Annales, quanto os marxistas, não conseguiram abalar de maneira efetiva os pilares do pensamento iluminista, a crença na ciência, e trouxeram à disciplina histórica a responsabilidade de ser uma ciência. A história problema, a história total e a história das mentalidades procuraram ser científicas, uma vez que estabeleceram um diálogo com outras áreas de conhecimento e nunca abandonaram o documento, criando métodos críticos para concebê-lo, mesmo depois de toda a crítica dos pais fundadores dos Annales aos positivistas alemães e sua crença na verdade documental, o documento histórico sustenta os trabalhos dos historiadores. Fazemos isso nos pautando na razão científica, numa razão iluminista.

\footnotetext{
${ }^{44}$ HARVEY, David. A condição Pós-moderna. Uma pesquisa sobre as origens da mudança cultural. Trad. Adail Sobral e Maria Estela Gonçalves. 17ª Ed. São Paulo: Edições Loyola, 2008; BERMAM, Marshall. Tudo que é sólido se desmancha no ar. A aventura da modernidade. $1^{a}$ reimpressão. São Paulo: Companhia das Letras, 1986. 
Os pilares da razão, em detrimento da fé, fundamentaram as linhas de pensamento que levaram à criação e ao desenvolvimento do topos filosófico ciência, de que resulta a noção de progresso. A crença na razão produziu a sociedade capitalista e a riqueza material, o individualismo, o liberalismo e a liberdade; produziu também a Medicina e as melhorias na saúde, a Engenharia e o desenvolvimento dos bens materiais. Em outras palavras, a política liberal, o livre mercado, o progresso científico e a inovação tecnológica. Todos esses pontos são as bases para a concepção de felicidade e progresso da sociedade moderna. ${ }^{45}$ A ciência moderna, portanto, atende ao mundo e à filosofia burguesa de cunho lluminista; e a sociedade Ocidental esteve embasada nesses principios durante dois séculos. Portanto, a historiografia esteve mergulhada nessa crença e na noção de que a disciplina histórica é uma ciência e busca a verdade científica, em maior ou menor medida. Esses pilares guiaram o trabalho do historiador no século passado e ainda guiam parte da historiografia, mesmo que de maneira inconsciente.

Evidentemente, devemos relativizar tais afirmações. Observamos o exemplo da primeira geração dos Annales, cuja principal crítica aos positivistas foi em relação à crença na objetividade pura do documento (preferencialmente oficial) como signo de verdade, quando o fato/acontecimento era o norteador da escrita histórica. Ao aceitar outras formas de documentos e outras ferramentas de outras áreas procuraram dar legitimidade científica à disciplina, não propriamente, torná-la acientífica.

Em posição crítica ao conceito de razão, de ciência burguesa, de verdade histórica, houve uma mudança de direção no âmago dos debates historiográficos, desencadeada pelo que os teóricos denominaram de movimento pós-moderno ou pós-modernidade:46 uma tentativa de superação dos preceitos da modernidade estabelecida. A ciência, tal como concebida pelos iluministas, sofre ranhuras teóricas na medida em que integra um dos sustentáculos do pensamento racionalista, fruto das teorias universalizantes e de narrativas lineares do século $\mathrm{XIX}{ }^{47}$

A condição pós-moderna aparece como decorrência da sociedade moderna, pelo desenvolvimento das máquinas, da imprensa, da televisão, de um mundo acelerado e

\footnotetext{
${ }^{45}$ HICKS, Stephen. Explicando o pós-modernismo. São Paulo: 2008. P. 23.

${ }^{46} 0$ termo pós-moderno começa a ser usado já no século XIX, mas, seu uso teórico e consciente se dá a partir de cerca de 1970. ANDERSON, Perry. Balanço do Neoliberalismo. In: EMIR, Sader; GENTILI, Pablo Gentil (Org.). Pós-neoliberalismo: As politicas Sociais e o Estado Democrático. 4. ed. Rio de Janeiro: Paz e Terra, 1995. p. 9 -23.

${ }^{47}$ HICKS, Stephen. Op. cit., p. 23.

Almanack. Guarulhos, n.15, p. $245-293$ 
repleto de informações velozmente multiplicadas. Configura-se, assim, uma necessidade contínua de produzir explicações na velocidade e abundância dos meios de comunicação. Com o desenvolvimento da internet, esse processo, nos parece, cada vez mais pujante. Ocorre que tal situação produziu uma sociedade com acesso muito rápido a bases de dados, artigos, notícias; mas, que se perde nessa imensidão de narrativas, pois, o excesso informativo é uma das mais efetivas induções ao esquecimento. ${ }^{48}$ Toda a produção material construída pela ciência iluminista acelerou o tempo e conseguintemente desbastou os pilares que sustentam o pensamento moderno.

Como os historiadores estão trabalhando com essa situação? Até décadas atrás, por exemplo, os pesquisadores relacionados à história do Brasil colonial tinham que viajar milhares de quilômetros em busca de documentos, para acervos no Rio de Janeiro, São Paulo, Pernambuco, Bahia, sobretudo, Portugal. Hoje, com poucos gigabytes de memória, em um HD externo, ele carrega consigo as mais de 350 mil páginas de arquivos do Projeto Resgate. ${ }^{49}$ Este artigo, por exemplo, foi escrito a partir de downloads de vários textos, como os da base de dados $\mathrm{Jstor}^{50}$ que, outrora, seriam de dificílimo acesso. Outro exemplo é a atual facilidade de consultar o número de africanos transportados da África às várias regiões do mundo, por meio do acesso ao site da Trans-Atlantic Slavery Data base. ${ }^{51} \mathrm{Em}$ sintese, temos acesso a um mundo virtual quase infinito de informações e a quantidade de artigos produzidos, como consequência, tende a ir ao encontro dessa aceleração pela rapidez da acessibilidade. 0 problema é: o que estamos fazendo com todo esse volume de informações? As pesquisas históricas depois da década de 1970 passaram a ser cada vez mais fragmentárias e locais. Nesse processo, começa a haver um descentramento do estruturalismo como elemento norteador das narrativas. ${ }^{52}$

0 linguistic turn ${ }^{53}$ foi uma ocasião decisiva no processo de mudança e crítica aos estabelecidos paradigmas estruturalistas da historiografia. 0 marxismo e a história totalizante dos Annales foram rigorosamente destronados de suas posições reinantes, para

\footnotetext{
${ }^{48}$ HARVEY, David, Op. cit. 315.

49 Nos referimos ao documentos da Torre do Tombo que também pode ser buscado na internet: http://www.cmd.unb.br/biblioteca.html

${ }^{50}$ http://www.jstor.org/

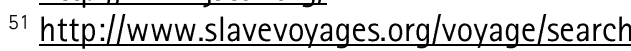

52 DERRIDA, Jacques. Gramatologia. Tradução Miriam Chnaiderman e Renato Janine Ribeiro. 2. ed. São Paulo: Perspectiva, 1999; DERRIDA, J. Positions. Trad. Alan Bass. Chicago: University of Chicago Press, 1981. FOUCAULT, M. Poder e saber. Rio de Janeiro: Forense Universitária, 2006.

${ }^{53}$ WHITE, Hayden. Meta-história. A imaginação histórica do século XIX. Tradução José Laurênio de Melo. São Paulo: Edusp, 1992 
dar espaço a uma história em migalhas. Os Annales, depois da história das mentalidades, desenvolveram a história cultural que atende, em certa medida, às críticas do movimento desconstrucionista, ${ }^{54}$ visto que não se pretende estrutural.

Esse aspecto do pós-modernismo foi reforçado pelas atividades dos desconstrucionistas. Em sua suspeita de toda narrativa que aspire a ter coerência, e em seu açodamento de desconstruir qualquer coisa que ao menos pareça uma metateoria, eles solaparam todas as proposições básicas. Na medida em que todos os relatos da narrativa oferecidos continham pressuposições e simplificações ocultas, havia necessidade de um escrutínio crítico, mesmo que este terminasse por fortalecê-la. Mas, ao desafiar todos os padrões consensuais de verdade e de justiça, de ética e de significado, e ao procurar dissolver todas as narrativas e metateorias num universo difuso de jogos de linguagem, o desconstrucionismo terminou, apesar das melhores intenções dos seus praticantes mais radicais, por reduzir o conhecimento e o significado a um monte desordenado de significantes. Assim fazendo, produziu uma condição de niilismo que preparou o terreno para o ressurgimento de uma política carismática e de proposições ainda mais simplistas do que as que tinham sido desconstruídas. ${ }^{55}$

$E_{1}$ com isso, os historiadores voltados para uma posição de esquerda começaram a mudar o foco dos seus interesses deixando de lado a luta de classes para pôr no centro do debate questões que a esquerda ortodoxa (sobretudo aquela ligada aos governos de esquerda, tais como na Rússia) considerava ser segundo plano.

A nova esquerda preocupava-se com uma luta para libertar-se das algemas duais da politica da velha esquerda, particularmente em sua representação por partidos comunistas tradicionais e pelo marxismo "ortodoxo", e dos poderes repressivos do capital corporativo e das instituições burocratizadas (o Estado, as universidades, os sindicatos etc.). Ela via a si mesma, desde o começo, como uma força cultural e político-econômica, tendo ajudado a produzir a virada para a estética que o pós-modernismo representava. ${ }^{56}$

Os textos de Michel Foucault muito contribuíram para essa mudança. ${ }^{57} \mathrm{~A}$ década de 1980 produziu ainda a falência na crença do marxismo como uma forma de conceber a história; isto é, esse fato comprovaria (material e politicamente) que não podemos

\footnotetext{
${ }^{54}$ DERRIDA, Jacques. Op. cit.

${ }^{55}$ HARVEY, David. Op. cit., p. 314

56 Ibidem. p. 319.

57 Para uma excelente análise do tema, observar: ALBUQUERQUE JÚNIOR, Durval Muniz de. História: a arte de inventar o passado. Ensaios de teoria da História. 2007. Bauru, Edusc. 
"prever" e que não podemos conceber o mundo de maneira geral, estruturada. Em última análise, o pós-modernismo também representa a frustração em torno da ciência e das suas certezas empiristas. Racismo e sexismo, por exemplo, tomam o lugar no campo de estudos, ou seja, a antiga formulação do opressor e oprimido e a luta de classes perdeu seu mote principal e agora atende às micro injustiças sociais.

Nesse momento da história, toda a verdade científica é questionada: "Para o pósmodernista, as certezas científicas sobre as quais os modernistas sempre trabalharam são todas como que variantes do paradoxo do mentiroso". ${ }^{58}$ Em suma, no final do século XX, os estudos passaram a incorporar a noção de subjetividade sociolinguística, cuja relatividade toma conta dos trabalhos acadêmicos. A semântica passa a ser a chave explicativa de alguns trabalhos, a palavra explica toda a sociedade. A realidade passa a ser vista como uma construção linguística, que atende a determinados grupos sociais, normalmente ocupantes do poder. Sobre esse movimento, concordamos com Harvey: "Com efeito, a hiper-retórica dessa ala da reação pós-moderna pode decair na mais alarmante irresponsabilidade." ${ }^{59}$

Em alguns pontos, podemos perceber pesquisas sérias voltadas para as esferas locais. Como exemplo, observamos o trabalho de Michael Foucault. Para ele, a ciência e 0 poder são categorias interligadas de variadas maneiras. Segundo o autor, ao longo do século XIX e XX houve um processo de aumento do controle sobre o corpo, determinantemente, nos casos da Psicologia e Medicina, que ele chama de corpos dóceis. 0 Estado e a Igreja não seriam, portanto, espaços para procurar a configuração do poder e, sim, as diversas micro-esferas da sociedade, nos discursos, nos pequenos pontos constitutivos de potência, na realidade multifacetada. Ou seja, para ele, o Estado não tem o poder de controle conforme, por exemplo, os socialistas modernistas afirmavam. Portanto, de nada adiantaria procurar a resistência contra o Estado, já que o discurso de poder não se assenta nele. ${ }^{60}$ Dessa linha de pensamento, derivam alguns pontos de contestação do pós-modernismo. No entanto, a irresponsabilidade, como diria Harvey, se encontra nos excessos de tal interpretação.

Em suma, na segunda metade do século XX configura-se um processo de crítica aos paradigmas estruturais, que buscavam nas teorias generalizantes as explicações para a

\footnotetext{
58 HICKS, Stephen.. Op. cit. p. 120

${ }^{59}$ HARVEY, David, Op. cit., p. 315

${ }^{60}$ Foucault, Michel. História da Sexualidade: A vontade de Saber. São Paulo, Graal, 1999. 
realidade. Grosso modo, em história pululam os trabalhos micro, locais e fragmentários. A história cultural, como novo paradigma, está imersa nesse contexto de valorização das características individuais, de grupos locais, de costumes específicos. Com tal virada, parte da esquerda historiográfica deixa de fazer uma crítica consistente e com propostas multifacetadas, deixa de lado os estudos sobre o proletariado e, acima de tudo, não se preocupa mais com a grande luta de classes, passando a criticar a esquerda tradicional, concebendo-a mesmo como passiva ou reacionária sobre questões de gênero e raça. ${ }^{61}$ Acreditamos que essa fratura no âmago do pensamento de esquerda é a ordem do dia para os pensadores dessa linha, pois, "ao fazer esse movimento, a nova esquerda tendia a abandonar a sua fé tanto no proletariado como instrumento de mudança progressista como no materialismo histórico enquanto modo de análise".62 0 materialismo histórico, como ferramenta de análise, agoniza perante os ataques pós-modernos. Assim surge o grupo de estudos ART, fruto desse novo universo de relações e paradigmas.

\section{Neoliberalismo}

0 neoliberalismo, surgido depois da Segunda Guerra Mundial, ${ }^{63}$ teve sua implantação política depois da década de 1970, como resposta à crise econômica que se abateu sobre o capitalismo, após o aumento exacerbado do preço petróleo. Com a crise econômica atingindo as empresas, a filosofia neoliberal conseguiu alcançar os principais governos do mundo; sobretudo com as eleições de Margareth Thatcher na Inglaterra, em 1979, e Ronald Reagan nos EUA, em 1980. Devido à importância desses países, e à hegemonia dos EUA, inicia-se um processo de desmonte do keyneisianismo em várias partes do mundo, isto é, ocorre uma rejeição coletiva à racionalização da economia pelo Estado. Como consequência, a privatização de setores estratégicos da sociedade - como saúde, segurança, educação, produção de bens e serviços - se torna a principal doutrina de governo ${ }^{64}$. Com o aumento da globalização, essas empresas passam a receber capitais estrangeiros e se tornaram multinacionais ${ }^{65}$, o que implica na desnacionalização dos capitais e na ascensão de grandes empresas.

\footnotetext{
${ }^{61}$ HARVEY, David. Op. cit., p. 319-320.

62 LOC cit.

${ }^{63}$ CERQUEIRA, Jackson B. Uma visão do Neoliberalismo: surgimento, atuação e perspectivas. Sitientibus. N. 39. Feira de Santana, 2008. P. 169.

64 Ibidem, pp. 174 - 175.

65 Ibidem. 
Durante a década de 1970, na ditadura de Pinochet, a América Latina foi um dos primeiros lugares a implantar o processo de desmonte do Estado. ${ }^{66}$ Mas, no caso do Brasil, que nos interessa aqui, iniciado nos anos $1980,{ }^{67}$ o processo teve sucesso como plano de governo de Fernando Henrique Cardoso, em 1994. A partir desse momento, inicia-se um processo de desarticulação das grandes empresas estatais (como a Ligth, a Vale do Rio Doce, sistema de telecomunicações, etc.) e a internacionalização do capital brasileiro, além de mudanças nas leis trabalhistas.

Segundo Valter Mattos da Costa, ${ }^{68}$ em sua dissertação de Mestrado, esse projeto neoliberal, assim como a cultura do pós-modernismo e a globalização, acabou por seduzir parte da intelectualidade brasileira que passou a escrever conforme esse pensamento. Isto é, deixando de conceber o Estado como o elemento norteador da sociedade e centralizando no capitalismo o motor de seu desenvolvimento.

Mas em que e como, interessa-nos saber, esse pensamento pode influenciar na escrita da história do Brasil Colonial? Boa parte dela, até então, tinha como ferramenta teórica o materialismo histórico e, com isso, explicava os problemas brasileiros a partir da formação do capitalismo: o Brasil, como demonstrado acima, havia se formado historicamente para ser alavanca para a acumulação primitiva de capital na Europa, sendo o mercado externo (que na década de 1990 passou a ser bem visto pelos neoliberais) 0 responsável por construir um país dependente do mercado externo. Não é por acaso que, como veremos a seguir, parte da historiografia brasileira, de maneira certamente inconsciente, passa a observar o capitalismo em formação não mais como o elemento que explicaria o atraso econômico do país, e sim como reflexo de uma formação social elitista e excludente.

\section{Antigo Regime nos Trópicos}

Em 2001 foi publicado o livro Antigo Regime nos Trópicos. Sob nosso ponto de vista, nele adota-se uma abordagem que pode ser considerada diferente do Sentido da

\footnotetext{
${ }^{66}$ ANDERSON, 1995. Op. Cit. p. 19.

${ }^{67}$ ALMEIDA, Mônica Piccolo. Reformas neoliberais no Brasil: As privatizações no Governo Fernando Collor e Fernando Henrique Cardoso. Tese de Doutorado. Universidade Federal Fluminense, Instituto de Ciências Humanas e Filosofia, Departamento de história, Rio de Janeiro, 2010. P. 225.

${ }^{68}$ COSTA, Valter Mattos. 0 Canto Da Seria. A influência pós-moderna na Historiografia. Fluminense do Antigo Regime nos Trópicos. 2014. 238 f. Dissertação (Mestrado). Universidade Federal Fluminense, Instituto de Ciências Humanas e Filosofia, Departamento de história, Rio de Janeiro, 2014.
} 
Colonização. A nova escola historiográfica, denominada ART em referência ao livro, no entanto, apenas se formou depois do ano 2000, principalmente com o contato cada vez mais constante com os estudos do historiador do direito, Antonio Manuel Hespanha. Até o final da década de 1990, não havia sido construída a proposta final que se diferenciou do modo de se conceber a história colonial tradicional. Os pilares da crítica já estavam prenunciados nos livros Homens de Grossa Aventura, do professor João Fragoso, de 1992, e no $O$ Arcaísmo como Projeto, de Fragoso e Manolo Florentino, de 1998. E por fim, não menos importante, no livro Em costas negras de Manolo Florentino.

Portanto, dividimos em duas as fases do grupo carioca, que se autodenominaram no início na primeira década do século XXI, no ART. Não se afirma aqui, portanto, que a segunda fase nega completamente a etapa que por conta do livro denominaremos de fase Arcaísmo como Projeto. Observamos-na como um periodo inicial do projeto ART.

\section{Primeira fase: "Arcaísmo como Projeto"}

As teses de Fragoso e Florentino, sintetizadas no livro Arcaísmo como Projeto, de 1993, derivam das laureadas pesquisas Homens de Grossa Aventura e Em Costas Negras,e ainda estão de certo modo presas ao paradigma estabelecido pelo Sentido da Colonização, uma vez que, outrossim, se ligam metodologicamente à tese de Cardoso.

Os livros de Fragoso e Florentino mostram que havia uma acumulação endógena na Colônia mediante a constatação de elites coloniais, ancoradas no comércio para se diferenciar socialmente dentro da Colônia. Os autores demonstram, sob uma perspectiva interna, um processo de acumulação de capital que por vezes extrapolava as arrecadações europeias, não caracterizando, assim, propriamente um sentido exportador para o Brasil: o capital mercantil se acumulava nas mãos de alguns colonos. A mesma lógica aplicava-se ao mercado de escravos.

Em Homens de Grossa Aventura: acumulação e hierarquia na praça mercantil do Rio de Janeiro, 1790/1830, se observa uma grande pesquisa documental em inventários, testamentos, escrituras nos tabelionatos e toda uma gama de documentos voltados para os negócios do Rio de Janeiro. Sendo assim, esse trabalho demonstra que havia uma camada de negociantes no Rio de Janeiro (homens de grosso trato) que formava a elite interna, acumuladora de capital. Estavam envolvidos com diferentes tipos de comércio: interno e externo. Segundo Fragoso, esses negócios superavam o valor do capital rural. Por 
isso, conclui ele, a economia colonial, ao contrário do que tradicionalmente se assegurava, estava voltada para os negócios internos.

João Fragoso e Manolo Florentino, em 1997, escreveram um artigo no qual deram a entender que a história econômica estava em decadência, e que tal situação teria resultado de problemas internos da área, pois o caráter globalizante e estrutural de suas abordagens (referência à história econômica serial) teria deixado de fazer sentido à sociedade. Dessa maneira, suas críticas se direcionam ao marxismo e aos Annales da segunda geração, que tratam a história sem dar importância às pessoas e ao particular. Em 2002, ainda que João Fragoso deixe de ver a história econômica de maneira tão pessimista, continua a afirmar que se necessita de uma reconstrução da perspectiva de uma história econômica pelo viés local. ${ }^{69}$

$\mathrm{Na}$ época, apresentamos um balanço bastante cético sobre os destinos das pesquisas neste campo. A crítica avassaladora, e algumas vezes injusta, feita à história serial francesa, os modismos da historiografia brasileira e, com eles, a redução brutal do número de investigações econômicas feitas nas pós-graduações nos levaram àquele pessimismo. Passados alguns anos, a minha avaliação mudou um pouco. ${ }^{70}$

A despeito do câmbio de pensamento, as críticas e a afirmação de quase inutilidade da história econômica labrousseana para a realidade brasileira ainda continuam; Fragoso elege sua maneira de pensar, se diferenciando do tradicional modo de escrever a história do Brasil e, para isso, começa a atacar as bases dessa historiografia. Seu principal interlocutor passou a ser Fernando Novais, depositário desse modo de conceber a história. Portanto, tudo sugere que a preocupação com a desconstrução da importância dos Annales da segunda geração e do marxismo está estrategicamente direcionada à formação francesa e marxista de Novais e sua evidente influência na escrita da história do país. Nesse sentido, Fragoso ainda desqualifica a teoria da dependência que marca a obra do pesquisador paulista.

Uma dissertação recente defendida no Rio de Janeiro pode nos auxiliar na compreensão do viés adotado pelos autores cariocas, em que Fragoso é o mais

\footnotetext{
${ }^{69}$ FRAGOSO, João \&t FLORENTINO, Manolo. História econômica, CARDOSO, Ciro \&t VAINFAS, Ronaldo. (org.) Domínios da história. Rio de Janeiro: Campus, 1997; FRAGOSO, João. Para que serve a história econômica? Notas sobre a história da exclusão social no Brasil. Estudos Históricos. Rio de Janeiro, n² 29, 2002, p. 3·28. 70 Ibidem, p. 4. 
proeminente. 0 Canto Da Sereia ${ }^{71}$ : A influência pós-moderna na Historiografia Fluminense do Antigo Regime nos Trópicos, de Valter Mattos Costa, aponta no grupo uma tendência neoliberalista (não se sabe se consciente ou inconsciente) que resulta em uma interpretação positiva do sistema econômico neoliberal que tende a isentar o capitalismo como gerador dos problemas históricos brasileiros:"Principalmente, sugiro a hipótese de que, ao longo da história da sociedade brasileira, observou-se a contínua criação e recriação de mecanismos que se traduziram na exclusão social. ${ }^{172}$ Desse ponto de vista, a recriação da desigualdade social teria ocorrido mediante a gradual acumulação interna de capital no país.

Quais seriam, pois, as consequências dessa hipótese? Para responder a essa questão devemos perguntar ao autor quais seriam os mecanismos de produção das desigualdades. A resposta para essa questão é o ponto que dá sustentação a todas as suas teses e, consequentemente, influencia dezenas de outros trabalhos, teses e dissertações defendidas em seu círculo de produção acadêmica, fator que, entre outros pontos, vai ser o marco da fundação do grupo de estudos Antigo Regime.

Desse modo, para os autores do ART, o que explicaria os problemas brasileiros seria a acumulação endógena de capitais. Em outros termos, haveria uma camada de homens de grosso trato que, por meio do tráfico de escravos e dos negócios cariocas, teria acumulado boa parte das riquezas do país, assim reproduzindo, de geração em geração, as bases da desigualdade. Teria havido uma constante reiteração das desigualdades sociais por meio do acúmulo interno de capitais, uma tese sedutora, mas que passou a receber críticas.

Segundo Stuart Schwartz, havia certa contradição nessa tese principal que se assenta na reafirmação do caráter centralizador do poder interno dos negociantes como essência do capital, e que por outro lado, não deixa de mostrar o grande poder externo das negociações.

Fragoso enfatiza a importância do mercado interno, mas demonstra continuamente (e corretamente) suas ligações com o setor de exportação, o que cria uma certa tensão em seu argumento, oscilando entre a novidade de suas afirmações e o reconhecimento da

\footnotetext{
${ }^{71}$ COSTA, Valter Mattos. 0 Canto Da Sereia. A influência pós-moderna na Historiografia. Fluminense do Antigo Regime nos Trópicos. Dissertação (Mestrado Departamento de História). Universidade Federal Fluminense, Niterói, 2014

72 FRAGOSO, João. Para que serve a história econômica? ... p. 4. 
ligação íntima entre a economia interna e o comércio de ultramar. Caio Prado Júnior e outros, em seus escritos, já havia dedicado bastante atenção aos não proprietários ou pequenos produtores e ao mercado interno, mas continuavam a afirmar o caráter dinâmico dos setores ligados à economia de exportação. A inovação do trabalho de Fragoso está justamente no argumento de que o mercado interno teria passado a impulsionar a economia como um todo. ${ }^{73}$

Por isso, da afirmativa na qual se exibe, de forma convincente, que a economia interna impulsionava a economia global da Colônia, não se pode concluir que ela estava desligada do fator externo, tal como é colocado por Caio Prado Júnior. Conquanto, de fato, ele tenha evidenciado uma acumulação endógena, não sinalizou que o mercado era disjuntamente ligado à Europa.

Outro ponto a ser considerado é que a análise do livro de Fragoso abarca o final do século XVIII e início do XIX; não obstante, busca englobar toda a história da colonização. Ressaltamos que o final do século XVIII sofreu mudanças muito grandes em relação à economia tanto europeias quanto coloniais. Por exemplo, com o desenvolvimento de Minas Gerais, dinamizou-se a do Brasil, com a migração de inúmeros colonos e de muitos escravos para as zonas produtoras. Tal crescimento vertiginoso implicou na necessidade de uma maior produção interna para abastecer essas zonas. 0 u seja, não havia espaço para 0 tamanho da estrutura comercial apontada pelo autor nos princípios da colonização. 0 século XIX era completamente diferente dos séculos anteriores. Sobre esse ponto, 0 próprio Fragoso pondera:

Apesar desse recorte temporal, aqueles trabalhos, inclusive o meu, possuíam o velho vício e a arrogância da tradição ensaísta brasileira, qual seja: a tentação de, a partir de investigações de apenas um curto periodo e uma região, explicar, por meio de esquemas lógicos, o conjunto temporal da sociedade escravista da América lusa, inclusive seu vasto período colonial (de 1500 a 1822). ${ }^{74}$

0 problema do livro Homens de Grossa Aventura reside na interpretação estrutural da história focalizada a partir dos homens de negócio como motor da economia colonial, suplantando a grande produção voltada para o mercado externo. Esta é a síntese contida

\footnotetext{
${ }^{73}$ SCHWARTZ, Stuart. Mentalidades e estruturas sociais no Brasil colonial: uma resenha coletiva. Economia e Sociedade. Campinas, (13): 129-153, dez. 1999. P. 131.

${ }^{74} F R A G O S O$, João. Modelos explicativos da chamada economia colonial e a ideia de Monarquia Pluricontinental: notas de um ensaio. In: História (São Paulo). V. 31. N 2. 2012. P. 111. 
em seu trabalho conjunto com Florentino, Arcaísmo como projeto. Segundo os autores, há um projeto de implantação do Antigo Regime europeu no ambiente colonial que utiliza o capital com a finalidade de sustentação do ancien régime português. 0 livro Em Costas Negras demonstra a formação da gente de grosso trato no que se refere ao tráfico de escravos, fator subsequente aglutinante de capital colonial. Assim, tanto Fragoso quanto Florentino propõem uma explicação para toda a história do Brasil colonial, estudando um fragmento da história, e acabam por observar suas teses serem questionadas enquanto um quadro metodológico que explica todo o Brasil Colônia. Por isso, as pesquisas continuam com a intenção de procurar comprovar essa hipótese em todo o Brasil colonial. Estariam os autores propondo a existência de uma outra estrutura histórica no Brasil?

Para realizar tal comprovação houve a necessidade de algumas mudanças metodológicas e, com isso, consolida-se na década de 2000 o grupo Antigo Regime nos Trópicos, quando adotam teorias européias, de vieses pós-modernos, para justificar sua hipótese. Caracterizamos como segunda fase essa virada na maneira de escrever a história.

\section{Segunda fase: Antigo Regime nos Trópicos}

A segunda fase foi marcada, principalmente, pela criação de um grupo de estudos e pela utilização das teses do Arcaísmo em monografias. Frente às críticas, observou-se a insistência em comprovar historicamente, por meio de teses e dissertações - defendidas principalmente na UFRJ - a extensão estrutural dos homens de negócio como aglutinadores de capital. Com o passar dos anos, inúmeras outras instituições foram aderindo à interpretação proposta pelos professores cariocas.

Porém, um conjunto de fatores recrudesceu as pesquisas e fortaleceu esse grupo de estudos: estudar o império português tornou-se mais importante que estudar somente a Colônia. Acreditamos que essa mudança aconteceu por volta dos anos 2000, com o estudo fundamentado nos textos do autor português António Manuel Hespanha. ${ }^{75}{ }^{76}$ Devido a essa relação entre o ART e os estudos portugueses, dois pontos mudaram: primeiro, houve

\footnotetext{
${ }^{75} 0$ arcabouço teórico se encontra neste livro, que tem uma primeira edição espanhola de 1989. HESPANHA, António Manuel. As Vésperas do Leviathan. Coimbra: Livraria Almedina, 1994.

${ }^{76}$ Em 2000 há a publicação do artigo FRAGOSO, João; GOUVÊA, Maria de Fátima S. e BICALHO, Maria Fernanda Baptista. Uma leitura do Brasil Colonial. Bases da materialidade e da governabilidade do Império. Neste artigo há as bases de um estudo que se seguiu e que buscava entender a história colonial dentro do Império português. 
certo rompimento com a linguagem marxista; segundo, passou-se a valorizar os estudos políticos em detrimento dos econômicos. Estes passaram a compor subtópicos do primeiro. Assim, os estudos passaram a ter como objeto de apreciação o império português, especialmente, voltados para uma análise de sua história política, sem que deixasse de se preocupar com a formação do capital econômico na Colônia e de maneira a reforçar a ideia de concepção e manutenção de uma elite colonial de forma historicamente reiterada.

Cabe ressaltar também que a altercação passou a girar em torno da governabilidade do império, em relação à centralidade do poder real e ao modo como o Estado interferia na vivência da Colônia. Com esse tipo de interpretação, surgiu a possibilidade de diminuir ainda mais a importância histórica do meio rural, escravista e exportador e valorizar os micro-focos internos de poder aglutinadores de capital, o micro-poderes políticos, as câmaras municipais, etc. ${ }^{77}$

\section{Absolutismo Monárquico em debate}

Como já evidenciamos, as influências sobre as pesquisas do grupo que se formou com o surgimento do livro Antigo Regime nos Trópicos vieram de Portugal, do antigo país colonizador; e, mais precisamente, da adaptação dos estudos que circundam as teorias de António Manuel Hespanha, que aplica em Portugal o questionamento teórico acerca do poder monárquico português, de maneira a descaracterizar a imagem de um rei absoluto tal como concebido pelos estudos coloniais clássicos.

Publicado na Espanha, em 1989, o livro As vésperas do Leviatã procurava demonstrar que, em Portugal, o rei não possuía poderes irrestritos e que, nesse sentido, deixava o governo local para os órgãos localmente responsáveis. Em 1991, Pujol fez um balanço historiográfico a respeito da questão e chegou à conclusão de que a ideia de um estado privilegiado, centralizado, adveio primeiramente da caracterização de Alexis de Tocqueville sobre a Revolução Francesa, na qual sinalizou, de forma negativa, a excessiva interferência do rei nas decisões cotidianas dos súditos. Contudo, Pujol alerta para não se interpretar as mesmas localidades de forma antagônica ao centro. Se auto-regiam era de forma

\footnotetext{
77 Observe os vários capítulos que compõem os livros nas Tramas da Rede, Antigo Regime nos trópicos, etc. Almanack. Guarulhos, n.15, p. $245-293$ 
inequivocamente espontânea e não para se contrapor aos interesses reais, pois, não havia uma tensão dicotômica nesse sentido ${ }^{78}$.

0 rei era uma figura que tinha poderes, mas se sustentava apenas pela elite do mundo político que o cingia. Um pouco sem expressão na década de 90, e limitada ao grupo que cercava o Hespanha, a tese ganhou força, principalmente, com a adaptação da ideia de poder também estendido às Colônias, principalmente americana - o que não havia composto o rol de estudos até então. ${ }^{79}$ Talvez, exceto o livro As vésperas do Leviatã, o melhor exemplo de aplicação de pesquisas portuguesas sejam os vários capítulos do livro organizado pelo próprio Hespanha para a coleção História de Portugal. ${ }^{80}$ Neste livro, há um aprofundamento da tese de descentralismo político em Portugal que demonstra em variados pontos das localidades portuguesas o autogoverno.

\section{A Autonomia Colonial}

Frente aos estudos que explicam a descentralização do poder real, do ponto de vista político, surge a nova tese de um Antigo Regime nos Trópicos. Aceitando-se a descentralização da Coroa portuguesa, rápida e facilmente, os autores foram tentados a aplicar tal teoria às Colônias. Desse ponto de vista, portanto, teria se dado a ruptura final com a ideia de Sentido da Colonização e Sistema colonial. Em última análise, aquilo que foi concebido como uma variável interna em Ciro Flamarion Cardoso, de um ponto de vista conjuntural, pode ser entendido com um aspecto fundamental da estrutura histórica do Império: a descentralização.

Concluímos que frente à necessidade de superação das teses do ASC, cujo centro da explicação pautava-se na concepção de um rei com poderes absolutos, o conceito de descentralização encaixou-se perfeitamente à proposta do ART. Ao conceber Hespanha como mentor intelectual basilar de seus trabalhos, ${ }_{1}^{81}$ há uma ruptura definitiva nos

\footnotetext{
${ }_{78}$ PUJOL, Xavier Gil. Centralismo e Localismo? Sobre as Relações Políticas e Culturais entre Capital e Territórios nas Monarquias Europeias dos Séculos XVI e XVII In: Penélope. Fazer e desfazer história. N. 6. (Setembro de 1991).p. 134.

${ }^{79}$ Explica-se também pelas inúmeras palestras e cursos que Hespanha passou a realizar pelo Brasil, a partir dos anos 2000.

${ }^{80}$ HESPANHA, António Manuel. Introdução. In: MATTOSO, José (Direção). História de Portugal. HESPANHA, A. M. (Coordenação). 0 Antigo Regime. (1620 - 1807). Vol. 4. Lisboa: Estampa, 1998.

${ }^{81}$ Francisco Cosentino publica em 2014 um artigo no qual faz uma "leitura" de António Manuel Hespanha demonstrando que o autor tem muita influência sobre a "historiografia" colonial. Demonstra também a sua inserção no contexto de produção historiográfica norteada por Michel Foucault e toda uma discussão politica sobre os micro-poderes COSENTINO, Francisco Carlos. Governadores Gerais do Estado do Brasil. Almanack. Guarulhos, n.15, p. $245-293$ 
métodos utilizados na escrita histórica. Fruto do pós-modernismo, os textos de Hespanha remetem a um cisma com o estruturalismo e o marxismo. Visto de uma forma dicotômica, a interpretação fundamentada no Antigo Sistema Colonial começa a perder legitimidade perante a concepção do rei que tinha poderes limitados. Ora, de que modo sustentar-se-ia a noção de Pacto Colonial se de forma alguma as Colônias existiam para atender ao aparato metropolitano? A ideia de uma exploração colonial seria também minimizada, já que as Colônias não eram um corpo do qual o rei, de forma parasitária, extraia suas rendas; retomando-se, sobretudo, as teses colocadas em Homens de Grossa Aventura e Arcaísmo como projeto, de que a economia basilar da Colônia se voltava para os homens de grosso trato, sendo a propriedade rural baseada no escravismo pouco importante. Em vista disso, distanciam-se cabalmente as interpretações do ART e as do ASC. 0 grupo que antes apontava a insistência na influência exploradora do Brasil Colonial (assim como as teorias neoliberais na década de 1990), negaram por consequência a teoria da dependência, bem como agora os poderes dos reis absolutos, uma vez que todos esses fatores foram narrados concatenadamente. Vejamos.

Em Antigo Regime nos Trópicos há um importante artigo de Hespanha que acomoda sua tese de Monarquia Corporativa em relação às Colônias. Observemos alguns pontos traçados por ele:

- Poder real partilhava o espaço político com poderes de maior ou menor hierarquia;

- 0 direito legislativo da Coroa era limitado e enquadrado pela doutrina jurídica (ius commune) e pelos usos de práticas jurídicas locais;

- Os deveres políticos cediam perante os deveres morais (graça, piedade, misericórdia, gratidão) ou afetivos, decorrentes de laços de amizade, institucionalizados em redes de amigos e de clientes;

- Os ofícios régios gozavam de uma proteção muito alargada dos seus direitos e atribuições, podendo fazê-los valer mesmo em confronto com o rei e tendendo, por isso, a minar e expropriar o poder real. ${ }^{82}$

(Séculos XVI-XVII). Oficios, regimentos, governação e trajetórias. São Paulo: ANNABLUME/FAPEMIG, 2009. P. 72-74

82 HESPANHA, António Manuel. A constituição do Império português. Revisão de alguns enviesamentos correntes. In: FRAGOSO, João; BICALHO, Maria Fernanda e GOUVÊA, Maria de Fátima, et al (org.). 0 Antigo Regime nos trópicos: A dinâmica imperial portuguesa (século XVI-XVIII). $2^{2}$ edição. Rio de Janeiro: Civilização Brasileira, 2010. pp. 166-167. Acreditamos que essa distância territorial não constituia um problema administrativo, sendo a afirmação anacrônica. 
Desse modo, os capitulos do referido livro visam expor, com variadas pesquisas documentais, os diversos modos pelos quais as localidades detinham o poder de se autoadministrarem. Percorramos um pouco pelo trabalho de Francisco Cosentino, ${ }^{83}$ cuja tese de Doutorado segue a linha de pensamento de Hespanha. 0 autor afirma que governadores gerais tinham amplos poderes ao tratar das questões coloniais, não necessitando pedir, a todo momento, autorização real para realizar suas ações. 0 governador geral era, assim, um representante local do rei que exercia função similar à dele, podendo legislar quando fosse imprescindivel. Todos os outros cargos estavam submetidos a ele. 0 argumento que pesa para o rei não ter poder de decisão na vivência colonial, deixando-o nas mãos dos governadores é abalizado na distância entre as Colônias e a Metrópole, que nas contas de Hespanha conputava nove meses, ${ }^{84}$ o que dificultava ainda mais um controle central. Para Consentino, assim como para Hespanha, é um equívoco acreditar que o rei exercia poderes absolutos na vivência da Colônia. Ao explicar a provável ocasião que levou os historiadores a conceberem o poder monárquico da época moderna como resultado de um absolutismo, Hespanha chama atenção para uma análise retrospectiva, feita a partir da imagem do Estado do século XIX, e deturpada por propostas políticas que observavam negativamente o poder central do rei.

Do ponto de vista do colonizador, a imagem de um império centralizado era a única que fazia suficientemente jus ao gênio colonizador da metrópole. Em contrapartida, admitir um papel constitutivo das forças periféricas reduziria o brilho da empresa imperial. Do ponto de vista das elites coloniais, um colonialismo absoluto e centralizado condiz melhor com uma visão histórica celebradora da independência. ${ }^{85}$

Os historiadores brasileiros teriam passado a estudar a história da Colônia sob um ângulo retrospectivo, valorizando excessiva e continuamente uma visão antagônica da relação entre a Metrópole e a Colônia, que estabelece uma continuidade interpretativa e representa a posição política dos pró-independentistas do século XIX. Os alicerces da historiografia brasileira foram construidos no contexto imediato do pós-independência. Não por acaso, esses historiadores expressaram uma aversão na relação Metrópole/Colônia. Em última análise, uma visão própria dos colonizadores e colonizados

\footnotetext{
${ }^{83}$ COSENTINO, Op. cit.

${ }^{84}$ HESPANHA, António Manuel. Imbecillitas. As bem-aventuranças da inferioridade nas sociedades de Antigo Regime. São Paulo: Annablume/UFMG, 2010, p. 50.

${ }^{85}$ HESPANHA, A constituição do Império português ... p. 168.

Almanack. Guarulhos, n.15, p. $245-293$ 
passou a ser pensada de maneira sistemática a partir do esquema colonial do século XIX, no qual prevalece uma mentalidade marcada pela noção de exploração da Colônia pela Metrópole em um sistema de trocas desiguais projetado e moldado pelos interesses da burguesia aspirante à ascensão social.

0 efeito mais perturbador da aplicação de um modelo corporativo à situação colonial é o questionamento do paradigma de uma ligação de dependência única e unilateral entre metrópole e colônias, uma ligação que a história colonial tradicional compreende como 'exploração' e 'coerção'. Numa sociedade pluralista como aquela da Europa da baixa Idade Média e início da Época Moderna, exploração e coerção, mesmo quando elas existiram (e existiram muito frequentemente), eram canalizadas por um mecanismo muito complexo e diversificado: transferência de impostos, hierarquização simbólica, desigualdades jurídicas etc., que frequentemente desempenhavam papéis divergentes e mutuamente dissonantes ou mesmo conflituais. A tentativa de compreender a totalidade da história colonial com a história de uma relação monótona que submete colonizados a colonizadores é, vistas as coisas assim, uma simplificação grosseira, pouco aceitável pelas atuais regras de arte da história. $E_{1}$ já que falamos em colonizadores e colonizados, terminamos com a desconfortável questão de perguntar quem eram os colonizadores e quem eram os colonizados. Ou melhor, se os colonizadores eram o reino e se os colonizados eram os colonos de origem europeia e sua mestiçagem, onde colocamos os nativos? ${ }^{86}$

Nesse sentido, aceitando-se as bases de uma sociedade na qual não se privilegiava a coerção social, decorrente de trocas econômicas desiguais sistematicamente planejadas, torna-se incoerente pensar que o sentido da colonização tenha sido a vivência de uma Colônia em função da Metrópole. Menos provável ainda é a ideia de um projeto de colonização baseado num pacto social como sustentáculo de uma divisão desigual entre a Colônia e a Metrópole. Colônia versus Metrópole é resultado, segundo Hespanha, de uma interpretação ligada politicamente a um tempo histórico que serviu de protótipo para toda uma narrativa historiográfica, de certo modo anacrônica. Depreende-se que a escolha metodológica segundo a qual não se concebe a vivência colonial como resultado de um

\footnotetext{
${ }^{86}$ HESPANHA, Imbecillitas. As bem-aventuranças ... p. 75. 
processo coercivo, não acomodaria, por conseguinte, a ideia de uma Colônia que tinha por função exportar para desenvolver a Metrópole.

\section{0 político e novo viés de estudo da Colonização}

De forma oposta ao modo de conceber do ASC, que tem seus alicerces na história econômica, marxista, quantitativa, o grupo do ART passou a se basear na história política do Império como item principal de sua análise. Esses estudos, também decorrentes da discussão relativa ao absolutismo monárquico, expuseram como trabalhava a rede de poder que circundava as decisões dos reis. Tais pesquisas apontaram para a existência de uma sociedade corporativa que se baseava num pacto político em que cada camada social tinha sua função dentro do Antigo Regime, cabendo ao rei decidir, como cabeça de um corpo social, os rumos políticos, econômicos e culturais da sociedade. Passou-se, assim, a valorizar a noção de monarquia pluricontinental e monarquia compósita. Em última instância, havia a Coroa central na qual coabitavam os vários reinos do Império, respeitando os seus direitos, seus deveres e seus modos de se autoadministrarem. Monarquia constituida por grupos locais espalhados pelo império que igualmente dependiam do reconhecimento e do aval institucional da coroa para manter suas posições sociais diante das sociedades em que viviam. Monarquia pluricontinental porque ao mesmo tempo era uma monarquia corporativa. Coroa e ultramar eram faces de um mesmo edifício social, posto que ambos dependiam um do outro para se organizar com áreas de poder - político, econômico e cultural -, tendo suas jurisdições e prerrogativas reiteradas e reforçadas pelos vínculos que os articulavam, formando, desse modo, o conjunto imperial. ${ }^{87}$

A grande valorização dos reinos que constituíam o corpo do Império minimiza, consequentemente, a posição de submissão das Colônias, excluindo qualquer tentativa de conceber a história colonial em sob uma noção de exploração econômica. Nessa política imperial se destacam os acordos fundamentados nas prestações de serviços ao rei, os quais rendiam inúmeras mercês, cargos etc. Como são exemplos os insurretos de Pernambuco (1654) e Salvador Correia de Sá em Angola (1648), cujas posições políticas a favor do rei, e do bem comum, Ihes renderam mercês e cargos findadas as batalhas de que

${ }^{87}$ FRAGOSO, J. \&t GOUVÊA, M. de Fátima. Na Trama das Redes. Política e negócio no império português, séculos XVI-XVIII. Rio de Janeiro: Record, 2010. P. 19 -20. 
participaram. Isto é, a economia do Dom era superior às trocas econômicas. Vejamos o que diz Fragoso sobre o assunto:

Segundo essa moral, os serviços prestados ao rei eram devidamente remunerados e assumiam a forma de concessão de terras e até de ofícios régios. Estas relações colocavam uma monumental máquina administrativa ultramarina em movimento e criavam formas sociais de produção. Como instrumento de gestão, as mercês dadas pelo rei permitiam 0 preenchimento de todos os postos da administração militar e civil da coroa. Em outras palavras, o posto de Vice-Rei da Índia ou de Governador do Estado do Brasil, assim como o de provedor da fazenda real de Luanda, eram preenchidos mediante mercês concedidas por Sua Majestade. Os postulantes a estes cargos os recebiam ou não, conforme os serviços prestados por eles e suas famílias à monarquia. ${ }^{88}$

A economia do Dom passou a ser um dos fatores de demasiada importância para 0 grupo do Rio de Janeiro, explicando quase todas as ações no Brasil colonial.

Em vista desses apontamentos, pode-se dizer que foram criadas duas margens na historiografia colonial, de modo que uma está em relação de oposição à outra, negando-a, enfrentando-a, contrapondo-a, anulando-a. Entender a história como resultado de um Sistema Colonial é negar, portanto, uma monarquia corporativa, pois, se para uns a essência da governabilidade está embasada na exploração, no enfrentamento, na dicotomia, para os outros ela se estabelece por meio do corporativismo, da dinâmica, do pluralismo dos poderes; o que equivale a dizer que (de um lado o poder é concebido como central e de outro é rizomático. ASC apóia-se no sentido econômico da colonização; ao ART compete demonstrar um sentido político. Para os primeiros o poder é central, parapulverizado; para uns o sentido da colonização é econômico, para outros é político.

Pela primeira vez na história da historiografia colonial posterior a Caio Prado Júnior, se observa uma alternativa dicotômica a ideia de sentido exportador da colonização. ${ }^{89}$ Aceitando-se ou não o novo método interpretativo, o surgimento do grupo ART estimulou os estudos relacionados ao período colonial de uma forma muito peculiar. Primeiro porque, em um momento inicial, os trabalhos foram se aquilatando nos arquivos de modo a subsidiar discussões que de alguma maneira se contrapusessem à convencional interpretação de sentido econômico: se passou a aperfeiçoar os trabalhos nos arquivos; segundo, porque tais apontamentos acabaram por incrementar a importância teórica de

\footnotetext{
${ }^{88}$ FRAGOSO, J. Modelos explicativos da chamada economia colonial ... p. 121.

${ }^{89}$ Não afirmamos que ela seja melhor, pior, mais ou menos coerente; para o momento, apenas diferente. 
uma revisão historiográfica; e, terceiro, por instigar a repensar internamente uma teoria edificada, isto é, conduzir a uma reavaliação interpretativa, que resultou em novos trabalhos. Nesse novo patamar historiográfico, e frente a essa refacção, surgiram respostas às críticas elaboradas pelos autores do Rio de Janeiro. Os eventos acadêmicos contribuíram muito e concentraram-se em espaço para as primeiras discussões, como o organizado pela ANPUH em 2003. ${ }^{90}$

0 livro Modos de Governar expressou um primeiro diálogo direto entre os grupos e, como consequente controvérsia, gerou a polarização teórica das abordagens. Em seu prefácio, Vera Ferlini defende a noção de centralização da abordagem relacionada ao Antigo Sistema Colonial, bem como a ideia de que seria inegável a inexistência de uma produção em grande escala voltada para o mercado europeu, mesmo aceitando-se as teorias do Antigo Regime nos Trópicos. Na introdução, feita por Fernanda Bicalho, esta autora reitera e postula as críticas feitas no livro Antigo Regime nos Trópicos. ${ }^{91} 0$ debate que se insere nos artigos que compõem o livro demonstra uma bilateralidade interpretativa no que concerne ao modo teórico da fabricação historiográfica. De um lado, se valoriza a produção econômica e, do outro, o valor político das relações sociais do Antigo Regime sem tecer, contudo, um diálogo profundo, o que seria muito produtivo intelectualmente, ao nosso modo de conceber.

Consideramos como a resposta mais embasada e detalhada o texto introdutório de Laura de Mello e Souza, em seu livro o Sol e a Sombra. ${ }^{92}$ Tais apontamentos devem ser delineados aqui, sobretudo devido à influência que a autora exerce no panorama da historiografia nacional. Consideramos, pois, sua posição como representante da expressão de um grupo de historiadores que se vincula ao modo de conceber a colonização como fruto do Sistema Colonial. ${ }^{93}$

\footnotetext{
90 BICALHO, Maria Fernanda e FERLINI, Vera Lúcia Amaral (orgs). Modos de Governar. Ideias e práticas políticas no Império Português. 2a edição. São Paulo: Alameda, 2007. Primeira edição é de 2005.

91 Ibidem.

92 SOUZA, Laura de Mello e. 0 Sol e a Sombra. Política e administração na América portuguesa. São Paulo: Companhia das Letras, 2006.

93 Não procuramos simplificar o debate historiográfico transformando a ideia de alguns historiadores em ideias que representam toda a historiografia. Tampouco, polarizar institucionalmente 0 debate num embate Rio de Janeiro versus São Paulo, pois, sabemos que por mais influência política que as instituições possam exercer sobre as pessoas, em última análise elas tem seus modos de pensar próprios. Por isso, ao elencar as idéias de alguns historiadores, destacando-os dos demais e dando-lhes poder transformando-os na própria expressão teórica, não acreditamos que os outros professores e demais pesquisados pensem da mesma forma, em dicotomia plena. Na USP e na UFRJ se encontram os principais "lugares sociais" que Almanack. Guarulhos, n.15, p. $245-293$ 
Dialogando com os autores do Antigo Regime nos Trópicos, Mello e Souza defende a teoria na qual embasa seus estudos e ainda demonstra as fragilidades existentes na linha oponente. 0 primeiro ponto a ser ressaltado compete ao conceito de descentralização do poder real. Entende a autora que havia certa fragmentação dessa força, mas, afirma que a insistência nesse tipo de abordagem gerou certo abuso no modo de se conceber a monarquia descentralizada. Nesse sentido, dialoga diretamente com António Manuel Hespanha:

0 apreço ao esquema polissinodal e à microfísica do poder levam-no a enfraquecer excessivamente o papel do Estado e a criar armadilhas para si só, sobretudo no capítulo que escreveu para uma coletânea brasileira, 0 Antigo Regime nos trópicos, organizado por João Fragoso, Maria de Fátima, Gouvêa Maria Fernanda Bicalho. Ali há insights originais, como a já referida crítica a Raymundo Faoro e a observação de que "a imagem de um Império centralizado era a única que fazia jus ao gênio colonizador da metrópole", mostrando, mais uma vez, a permanente contaminação ideológica sofrida pelo tema da administração, conforme destaquei no início deste capitulo. Mas, há também certo descuido quanto a especificidade do império português na América, que o leva a generalizar com base em situações próximas ao Oriente. ${ }^{94}$

Há, para ela, uma limitação explicativa acerca do Império português, e as generalizações originam uma miscelânea teórica ao abordar as colônias como um todo no Império. Concorda que, ideologicamente, a historiografia do século XIX influenciou a produção historiográfica. Apesar disso, assinala que a ideia de Antigo Regime nos Trópicos é, do ponto de vista metodológico, defendida por Hespanha, apontando uma contradição.

Longe de mim propor o abandono do conceito de Antigo Regime. Mas, acredito que, ao utilizá-lo deve-se ter a clareza quanto às suas implicações subjacentes ao seu uso, e sobretudo quanto à relação que algumas sociedades assim qualificadas estabeleceram com possessões externas à orbita europeia. 0 que houve nos trópicos, sem dúvida, foi uma expressão muito peculiar da sociedade de Antigo Regime europeia, que se combinou,

institucionalmente representam as pesquisas, na primeira em torno do grupo de estudos da Cátedra Jaime Cortesão, os segundos, no grupo ART. Mas, dificilmente podemos classificar ou polarizar nacionalmente 0 debate, que mesmo internamente há divergências, mesmo dentro das referidas instituições, há variantes teóricas. Ainda cabe ressaltar que dentro dos quadros teóricos existem interpretações próprias de cada "lado", impossivel de ser elencada neste pequeno texto, que tem o objetivo de pinçar as principais idéias e, não se nega, as mais polarizadas, às vezes, caricaturizadas. Pois, nos pontos extremos podemos perceber os limites das interpretações.

${ }^{94}$ SOUZA, Op. cit. 48-49. 
conforme as análises dos autores de 0 Antigo Regime nos trópicos buscaram programaticamente evitar, como o escravismo, o capitalismo comercial, a produção em larga escala de gêneros coloniais - que nunca excluiu a de outros, obviamente -, com a existência de uma condição colonial que, em muitos aspectos e contextos, opunha-se a reinol e que, durante o século XVIII, teve ainda de se ver com mecanismo de controle econômico nem sempre eficaz e efetivo, mas que integravam, qualificavam e definiam as relações entre um lado e outro do Atlântico: o exclusivo comercial. Em suma, o entendimento da sociedade de Antigo Regime nos trópicos beneficia-se quando considerada nas suas relações com o antigo sistema colonial. ${ }^{95}$

Mello e Souza procura acomodar, em certos sentidos, as posições conceituais do Antigo Regime e do Antigo Sistema Colonial, não deixando de reconhecer toda a produção do grupo carioca. Mas, aponta para os problemas interpretativos do livro Antigo Regime nos Trópicos: a renúncia da produção em larga escala e o escravismo incide de modo proposital.

Explicativamente, a supressão dos estudos acerca de tais elementos deve ser arrazoado em toda a produção historiográfica elaborada por João Fragoso, a da primeira fase: a ideia contínua que persiste ainda hoje em seu trabalho e do grupo é a de que embora tenha havido o escravismo, a produção colonial em grande escala, não se constitui como fator central da história colonial. Assim como Novais e Prado Júnior não se interessaram pela dinâmica interna, os autores, inversamente, também se furtam de apontar o escravismo e a grande produção. Chegando ao ápice da falta de importância atribuida aos estudos tradicionais, amiúde colocados, o império e as estruturas políticas ainda seriam (historicamente) aspectos mais importantes nas relações sociais do que a própria produção de gêneros tropicais.

Para incrementar a nossa elucidação desse importante debate, é imperioso expor, a par das críticas elaboradas pela autora de 0 Sol e a Sombra, a resposta de Hespanha ${ }^{96}$. Observe-se abaixo que o autor se refere à crítica de Mello e Souza em relação ao seu excessivo apego ao Direito. Explicando o ensejo, a autora sugere que o historiador do Direito se deixa iludir pelas explanações dos textos jurídicos e limita a historicidade de forma simplista e restrita às leis.

\footnotetext{
95 Ibidem. p. 67.

${ }^{96}$ HESPANHA, António Manuel. Caleidoscópio do Antigo Regime. São Paulo: Alameda, 2012. Primeira edição em artigo em 2007 no Almanack Braziliense. 
Daí que, ainda que alguns historiadores (do direito) andem obcecado com o Direito, não liga quase nada às leis do rei, embora possa ligar muito à doutrina dos juristas e à jurisprudência dos tribunais. Por outro lado, ligando muito a esta doutrina e esta jurisprudência, ele tem que estar a ligar também muito ao direito praticado, ao direito vivido, aos arranjos da vida. É que uma das características do direito comum era a sua enorme flexibilidade, traduzida no facto de o direito local se impor ao direito geral e de, na prática, as particularidades de cada caso - e não as regras abstratas - decidirem da solução jurídica. Isso quer dizer que a centralidade do direito se traduzia, de fato, na centralidade dos poderes normativos locais, formais ou informais, dos usos das terras, das situações "enraizadas" (iura radicata), na atenção às particularidades de cada caso; e, em resumo, na decisão das questões segundo as sensibilidades jurídicas locais, por muito longe que andassem daquilo que estava estabelecida(a) nas leis formais do reino. (...) Esta função "desreguladora" e "paralisante" do direito é imediatamente evidente a quem tiver trabalhado um pouquinho que seja com o direito desta época. Mas, para quem não passou por aí, direito significa antes imposição, cogência, execução, inflexibilidade, formalismo. ${ }^{97}$

De modo algum, nos parece, que a autora relacione Direito à coerção. De modo inverso, ela impugna a falta de historicidade e aplicabilidade da teoria na história. Pois, se percebe em Hespanha a confiança de que os costumes locais prevaleciam às leis portuguesas centrais, que os códigos legislativos portugueses não interferiam na vivência local. Mas, a questão que fica é: essa afirmativa pode ser considerada estrutural para todo o Império português, em todas as regiões e em todos os momentos históricos? No mesmo sentido, a autora afiança que o português trata de forma homogênea o império, no que se refere à distância, como sendo um fator que impossibilita a centralização do poder.

Ainda em sua resposta, Hespanha chama a atenção para o pouco que escreveu acerca da História Ultramarina e que o que dissertou está em concordância com o que já haviam anotado os melhores historiadores brasileiros "a versão que dou nesses artigos não tem nada de novo. Os melhores intérpretes da realidade histórica do Brasil colonial não dizem outra coisa".98 0 autor português refere-se a Caio Prado Júnior e sua linha de pensamento na qual pondera sobre a desordem administrativo-colonial. Para Hespanha, esse conflito apontado pelo autor paulista era sintoma da descentralização do poder. $\mathrm{Ou}$

\footnotetext{
97 Ibidem, p. 11-12.

98 HESPANHA, A. M. As Vésperas do Leviathan ... p. 23.

Almanack. Guarulhos, n.15, p. $245-293$
} 
seja, na falta de um código que previsse os acontecimentos coloniais, dava-se a liberdade de resolver os problemas aos mandatários locais. A cada caso novo, fazia-se necessário impor, amiúde contraditório, um novo regulamento.

Em outra ponta crítica, Laura de Mello e Souza exprobra enfaticamente o conceito de Antigo Regime, afirmando que o uso do termo pode ser equívoco, pois retoma uma construção do termo nas cercanias da Revolução Francesa, quando havia um fervor político em torno da ideia. Apesar de ter organizado a História de Portugal, 0 Antigo Regime, ter um artigo na coletânea Antigo Regime nos Trópicos, colaborar ativamente como mentor intelectual de um grupo que se autodenomina Antigo Regime nos Trópicos; e, ainda, de a presente resposta à crítica de Mello e Souza ter sido publicada em uma coletânea de textos denominada Caleidoscópio do Antigo Regime, Hespanha afirma:

Dou de barato que a expressão Antigo Regime é, pelo menos equívoca e, com isso, dispenso-me de analisar toda argumentação sobre o sentido de 'Antigo Regime' desenvolvida de p. 63 a 67. Realmente, eu nem uso essa designação nos títulos de meus textos, embora talvez a tenha utilizado, com um sentido meu próprio, porventura pouco ortodoxo..$^{99}$

0 conceito utilizado, Antigo Regime, implica uma gravidade histórica e conota uma posição política importante. Teria sido interessante observar qual o modo de conceber do autor em relação à problemática (ou seu sentido pouco ortodoxo), pois, o que se percebe é uma adaptação inexplicada e irrefletida de Alexis Tocqueville.

Por fim, sobre a importante concepção do conceito de Estado. Mello e Souza assevera que não é pelo fato do Estado dos séculos XVI ao XVIII não serem iguais aos do século XIX, e porvindouros, que isso expressaria a sua inexistência. Ele existia de forma diferente.

Segundo Hespanha, há um uso anacrônico do conceito de Estado para se tratar nas Coroas da época moderna, uma retroprojeção da noção futura de uma disposição política do período moderno. Nesse sentido, se observa nas interpretações sobre a Colônia, uma concepção equivocada sobre as monarquias, enxergando nelas funções que não lhes eram próprias, como a centralização do poder coercivo e regulador, parafraseando o título de seu livro principal, um Estado Leviathan. E assim ele define o que entende por Estado moderno:

\footnotetext{
${ }^{99}$ Ibidem, p. 32. 


\begin{abstract}
E a própria coroa, em estado de necessidade e em transe de perder até a face, frequentemente cobria os desmandos, ou com silêncio de presumida ignorância, ou com o manto do perdão ou mesmo com o alarde de uma mercê por tais serviços. Pode, realmente, dizer-se que o modo de governar do 'Estado moderno' era este, o de se deixar equivocar; e que exigir-lhe um poder mais efetivo não passa de uma retroprojeção da imagem que mais tarde se formou do Estado, nomeadamente desse Estado distante, exigente e dominador, que é "Estado com colônias" (ou o Estado nas "colônias"). ${ }^{100}$
\end{abstract}

Em sua concepção, a Coroa portuguesa não tinha poderes capazes de colocá-la nas esferas mais internas da população. As leis não eram coercitivas e sim diferentemente organizativas. A Coroa não era um estado absoluto, controlador e punitivo. Em junção a outra crítica da historiadora brasileira, a de que inexistem estudos do Antigo Regime sobre a escravidão, Hespanha argumenta sobre a inexistência de estudos que apontem para a escravidão entendida dentro do âmbito coercitivo do estado.

Talvez eu esteja enganado. Mas, então, é preciso que se me indiquem as fontes de onde constem as tais intervenções quotidianas de um Estado repressor dos escravos subordinados. Sem que existam estas provas, diferenciadas em relação há rara intervenção europeia do Estado contra os seus escravos do interior, terei que concluir que, afinal, "administrar uma sociedade composta predominantemente por brancos' era pouco diferente 'que fazê-lo quando o contingente escravo podia chegar - como chegava em algumas regiões - a 50\% da população". ${ }^{101}$

Em outras palavras, os escravos eram uma questão privada e a coerção era circunspecta pelos seus donos. Como acomodar-se-ia, portanto, uma teoria de estado opressor no Antigo Regime frente a dinâmica escravista?

Percebemos que há uma cisão na forma de se compreender o passado colonial e que essa tensão indica visões políticas diferentes, que não iremos aprofundar aqui. Entretanto, observamos como também apontou Costa em sua dissertação, que os autores cairam no Canto da Sereia. 0 ambiente historiográfico da década de 1990 foi propício para pesquisas desconstrutivistas e, frente às mudanças ocorridas com a entrada de FHC no poder e sua escolha pelo neoliberalismo, os autores passaram a adotar uma postura diferente perante o Estado e a economia, também, consequentemente em relação à história do Estado e sua ligação com o capitalismo. De certa maneira, o capitalismo, de uma forma mais ampla, deixa de receber tantas críticas quanto antes, justamente por conta da proposta política

\footnotetext{
${ }^{100}$ Loc cit.

101 Ibidem, p. 35.

Almanack. Guarulhos, n.15, p. $245-293$
}

artigos 
do neoliberalismo. Os autores dessa época, sobretudo os de formação nesse período, sofrem grande influência do regime. Quais as consequências dessa virada para a historiografia do Brasil Colonial?

\section{Considerações Finais}

Mediante o que até aqui expomos e discutimos, devemos pensar sobre o rótulo de revisionista que o grupo ART vem recebendo. Primeiramente, o revisionismo pressupõe uma profunda leitura e compreensão das teses consolidadas e, por conseguinte, uma proposta de superação. É preciso questionar, houve superação? Existe uma profunda leitura dos textos clássicos que fundamentam o ASC? Citamos aqui autores que influenciam o trabalho de Fernando Novais, como Eric Willians e Caio Prado Júnior. Outros, tais como Florestan Fernandes e Sérgio Buarque de Holanda. Quanto, por exemplo, do que é classificado como novo nos trabalhos de António Manuel Hespanha já não existia no clássico estudo de Eduardo D'Oliveira França, Portugal na época da Restauração? Ou em Os Donos do Poder de Raymundo Faoro? Mesmo o autor português se colocando como crítico dos brasileiros em alguns textos, como na introdução de As Vésperas do Leviathan, percebemos muitas vezes leituras superficiais sobre clássicos da historiografia brasileira.

Podemos, claramente, atrelar o surgimento do ART ao movimento pós-estruturalista, uma vez que, sintomaticamente, o grupo procura romper com o marxismo de Novais e seus discípulos por um viés desconstrutivista, embasando-se na teoria foucaultiana dos micro-poderes, lida à segunda mão, por intermédio da obra de António Manuel Hespanha. Tais posicionamentos implicaram na decisão de estudar os rincões do império e suas autonomias políticas. Para essa finalidade, as dissertações e teses receberam orientações nesse sentido. 0 absolutismo, o mercantilismo e ainda o escravismo sofreram com 0 processo de desconstrução historiográfica. As noções de absolutismo e mercantilismo, crítica historiográfica portuguesa, foram substituídas por um Estado descentralizado, polissêmico, ao gosto do pensamento neoliberal. Agora, o escravismo, retirado das páginas da histórica, não teve nada colocado no lugar, ficando um vazio. Sendo assim, termos com a exploração colonial, deixaram de fazer sentido, desaparecendo.

Sobre a crítica de Fragoso à história econômica, é, sobretudo, à história econômica marxista que ele se refere. 0 processo de rompimento com Ciro Flamarion Cardoso pode 
estar ligado ao movimento geral dos anos 1990 de atrelagem ao pós-modernismo. Muito se acomoda à tese do ART a perspectiva de caracterizar as deficiências e problemas econômico-sociais atuais não ao capitalismo externo, mas, à história interna, à acumulação interna. Paradoxalmente, lê-se nos trabalhos de Fragoso o desenho de uma estrutura histórica para pensar o Brasil, que é o auge de sua interpretação: desde que o Brasil se formou, acumula-se capital internamente e essa acumulação fez surgir na Colônia e no seu Brasil contemporâneo, anos 1990 e 2000, uma camada interna, elitista e acumuladora de capital. Essa tese é oposta às de Caio Prado e Fernando Novais. Na concepção do ART, em vez do problema estar no capitalismo explorador, está na formação de elites econômicas internas. Nosso problema não seria o capitalismo externo (tese da dependência), mas, a reiteração constante da desigualdade social.

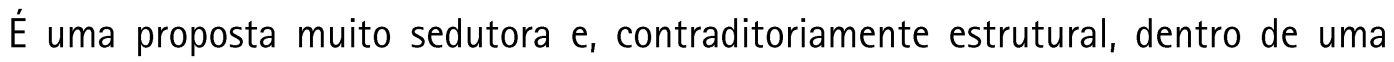
linha de pensamento marcada pelo pós-estruturalismo. Mas, seria essa estrutura conferível historicamente? É o que impulsiona e unifica o grupo, marcando as preocupações atuais dos seus trabalhos, que visam contestar a estrutura de um poder controlador do rei europeu com base nos ensinamentos de Foucault, via Hespanha. Por isso, o grupo reivindica uma autonomia das localidades de todo o Império português em relação ao centro. Essa autonomia, aliada a um pensamento de Antigo Regime, de privilégios de classe, influenciou a História do Brasil e a criação de classes que acumularam capitais. Mas, a intenção não era acumular capital e sim se diferenciar socialmente, à luz do conceito de nobreza da terra. Essa proposta é completamente diferente da abordagem teórica do ASC, segundo a qual o grosso do capital acumulou-se na Europa e não na colônia.

Ambas as explicações procuram dar respostas aos nossos problemas do presente, explicar as mazelas de nossa sociedade atual: Fernando Novais, no contexto da Guerra Fria, da criação da CEPAL, do estruturalismo; Fragoso, no contexto do pós-estruturalismo, do neoliberalismo, da falência das propostas políticas do comunismo.

Do ponto de vista da historiografia nacional, podemos afirmar que essa é uma quebra do paradigma proposto pelo sentido da colonização. Entretanto, até o momento, percebemos que para concretizar tal diferenciação, existem pontos forçados que devem ser melhor explicados, tais como a questão do escravismo, da produção de açúcar e das toneladas de ouro que saíram das diversas regiões brasileiras. Desclassifica-se a história 
econômica quantitativa, mas, como superar os números que apontam a saída de capital da Colônia rumo à Metrópole? Homens de Grossa aventura aborda o final do século XVIII e início do XIX, como levar esse raciocínio a todo o Brasil colonial?

Sendo assim, percebemos que a crítica ao estruturalismo e à história econômica é direcionada especificamente à história econômica e ao estruturalismo marxista, dos quais Novais é partícipe. 0 grupo ART fundamenta sua explicação numa história sustentada por uma estrutura histórica: a do acúmulo interno de capitais. Sua tese central é, com efeito, estrutural. Valoriza a política, mas, o ponto principal que ocorre o direcionamento da política de Antigo Regime é pelo viés da economia - o acumulo do capital.

Por fim, observamos positivamente a construção de um novo paradigma historiográfico que passou a valorizar mais as fontes, que fomentou os eventos sobre a história colonial - a exemplo, consolida-se e torna-se tradicional os Encontros internacionais de História colonial. Embora haja pontos que ainda precisam ser esclarecidos e elucidados, como ficou demonstrado no decorrer do artigo, o debate, que promove a ciência histórica, teve grande avanço nos últimos anos. Prêmios, como o Jabuti, o da Biblioteca Nacional, do Arquivo Nacional, passaram a figurar entre os trabalhos de História Colonial, dos quais destaca-se o Prêmio Jabuti oferecido a João Fragoso e Maria de Fátima Gouvêa pelo livro Brasil Colonial, em 2015. Ronaldo Vainfas, com a biografia de António Vieira, publicada em 2014; e Laura de Mello e Souza com a de Cláudio Manuel da Costa.

* Parte desse texto compõe nossa dissertação de mestrado, já defendida. SALLES, Wesley Dartagnan. Tempos de crises. 0 império português, a crise açucareira, tráfico de escravos e a lei das arqueações (1640-2695). 2014. Dissertação (Mestrado em História). Universidade Estadual Paulista Júlio de Mesquita Filho. São Paulo, 2014. A pesquisa contou com financiamento da FAPESP.

Data de recebimento do Artigo: 11/03/2016

Data de aprovação do Artigo: 10/01/2017 
Referências Bibliográficas:

ALBUQUERQUE JÚNIOR, Durval Muniz de. História: a arte de inventar o passado. Ensaios de teoria da História. Bauru: Edusc, 2007.

ALMEIDA, Mônica Piccolo. Reformas neoliberais no Brasil: as privatizações no governo Fernando Collor e Fernando Henrique Cardoso. Tese (Doutorado Departamento de História). Instituto de Ciências Humanas e Filosofia, Universidade Federal Fluminense, Rio de Janeiro, 2010.

ANDERSON, Perry. Balanço do Neoliberalismo. In: EMIR, Sader; GENTILI, Pablo Gentil (Org.). Pós-neoliberalismo: as políticas sociais e o Estado democrático. 4. ed. Rio de Janeiro: Paz e Terra, 1995.

BERMAM, Marshall. Tudo que é sólido se desmancha no ar. A aventura da modernidade. $1^{\text {a }}$ reimpressão. São Paulo: Companhia das Letras, 1986.

BICALHO, Maria Fernanda e FERLINI, Vera Lúcia Amaral (orgs). Modos de Governar. Ideias e práticas políticas no Império Português. 2a edição. São Paulo: Alameda, 2007. Primeira edição é de 2005.

BLOCH, Marc. Apologia da História ou ofício do historiador. Tradução: André Telles. Rio de Janeiro, Jorge Zahar Editor, 1997.

BRAUDEL, Fernand. Civilização material, economia e capitalismo: séculos XV - XVIII. Vol.

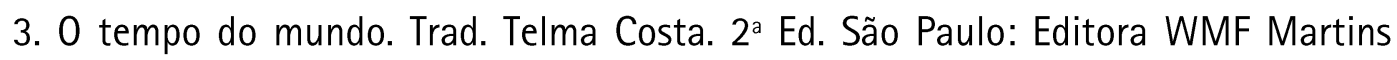
Fontes, 2009

CARDOSO, Ciro Flamarion S. A brecha camponesa no sistema escravista. In:

Agricultura, escravidão e capitalismo. Petrópolis: Vozes, 1979.

. Agricultura, escravidão e capitalismo. Petrópolis: Editora Vozes Ltda., 1979.

CEROUEIRA, Jackson B. Uma visão do Neoliberalismo: surgimento, atuação e perspectivas. Sitientibus. N. 39. Feira de Santana, 2008.

CERTEAU, Michel de. A Escrita da História. Rio de Janeiro: Forense-Universitária, 1982.

COSENTINO, Francisco Carlos. Governadores Gerais do Estado do Brasil. (Séculos XVI-XVII).

Ofícios, regimentos, governação e trajetórias. São Paulo: ANNABLUME/FAPEMIG, 2009.

COSTA, Valter Mattos. 0 Canto Da Sereia. A influência pós-moderna na historiografia fluminense do Antigo Regime nos Trópicos. 2014. 238 f. Dissertação (Mestrado 
Departamento de História). Universidade Federal Fluminense, Instituto de Ciências Humanas e Filosofia, Rio de Janeiro, 2014.

DERRIDA, J. Positions. Tradução. Alan Bass. Chicago: University of Chicago Press, 1981.

FOUCAULT, M. Poder e saber. Rio de Janeiro: Forense Universitária, 2006.

DERRIDA, Jacques. Gramatologia. Tradução Miriam Chnaiderman e Renato Janine Ribeiro.

2. ed. São Paulo: Perspectiva, 1999.

FERLINI, Vera Lúcia A. Terra, trabalho e poder. São Paulo: Brasiliense, 1988.

. Açúcar e colonização. São Paulo: Alameda, 2010.

FOUCAULT, Michel. História da Sexualidade: A vontade de Saber. São Paulo, Graal, 1999.

FRAGOSO, J. \&t GOUVÊA, M. de Fátima. Na Trama das Redes. Política e negócio no império português, séculos XVI-XVIII. Rio de Janeiro: Record, 2010.

Et FLORENTINO, Manolo. História econômica In: CARDOSO, Ciro \&t VAINFAS, Ronaldo. (org.) Domínios da história. Rio de Janeiro: Campus, 1997 . Homens de Grossa Aventura: acumulação e hierarquia na praça mercantil do Rio de Janeiro (1790-1830). Rio de Janeiro: Civilização Brasileira, 1998.

- Modelos explicativos da chamada economia colonial e a ideia de Monarquia Pluricontinental: notas de um ensaio. In: História (São Paulo). V. 31. N 2. 2012.

. Para que serve a história econômica? Notas sobre a história da exclusão social no Brasil. Revista de Estudos Históricos, Rio de Janeiro, v. 29, p. 3-28, 2002.

. E BICALHO, Maria Fernanda e GOUVÊA, Maria de Fátima. (org.). O Antigo Regime nos trópicos: A dinâmica imperial portuguesa (século XVI-XVIII). $2^{\text {a }}$ edição. Rio de Janeiro: Civilização Brasileira, 2010.

. Et GOUVÊA, Maria de Fátima S. e BICALHO, Maria Fernanda Baptista. Uma leitura do Brasil Colonial. Bases da materialidade e da governabilidade do Império. In: Penélope. N. 23, 2000.

FREYRE, Gilberto. Casa Grande e Senzala: Formação da Família Brasileira sob o regime patriarcal. 18 edição brasileira. Rio de Janeiro: José Olympio editora, 1977.

GODINHO, Vitorino de Magalhães. Os Descobrimentos e a economia Mundial. Vol. 1. 2a edição. Lisboa: Editorial Presença, 1971.

GORENDER, J. O escravismo colonial. São Paulo: Ática, 1978. 
HARVEY, David. A condição Pós-moderna. Uma pesquisa sobre as origens da mudança cultural. Trad. Adail Sobral e Maria Estela Gonçalves. 17ª Ed. São Paulo: Edições Loyola, 2008.

HESPANHA, António Manuel. "A constituição do Império português. Revisão de alguns enviesamentos correntes." In: FRAGOSO, João; BICALHO, Maria Fernanda e GOUVÊA, Maria de Fátima, et al (org.). O Antigo Regime nos trópicos: A dinâmica imperial portuguesa (século XVI-XVIII). 2a edição. Rio de Janeiro: Civilização Brasileira, 2010. . "Introdução". IN: MATTOSO, José (Direção). História de Portugal. In:

(Coordenação). 0 Antigo Regime. (1620 - 1807). Vol. 4. Lisboa: Estampa, 1998. . As Vésperas do Leviathan. Coimbra: Livraria Almedina, 1994.

HESPANHA, António Manuel. Caleidoscópio do Antigo Regime. São Paulo: Alameda, 2012. Primeira edição em artigo em 2007 no Almanack Braziliense. - Imbecillitas. As bem-aventuranças da inferioridade nas sociedades de Antigo Regime. São Paulo: Annablume/UFMG, 2010.

HICKS, Stephen. Explicando o pós-modernismo. São Paulo: 2008.

HOBSBAWM, Eric. The General Crisis of the European Economy in the 17th Century. Past \&t Present, n 5. 1951.

HOLANDA, Sérgio Buarque de. Raízes do Brasil. $3^{a}$ edição. São Paulo: Companhia das Letras, 1997. Primeira edição de 1936,

IGLÉSIAS, Francisco. Historiadores do Brasil. Rio de Janeiro/ Belo Horizonte: UFMG/Nova Fronteira, 2000.

MAROUESE, Rafael. Capitalismo e escravidão e a historiografia sobre a escravidão nas Américas. Estudos. vol. 26. n. 75. São Paulo, 2012.

MATHIANS, Carlos Leonardo Kelmer. A tese de Williams e o Antigo Sistema Colonial: notas sobre um debate clássico. História da historiografia. Ouro Preto, n. 11, abril, 2013. Pp. 190-209.

MENDES, Claudinei M. "Um estudo sobre a relação entre Caio Prado Júnior e Fernando A. Novais". Acta Scientiarum. Human and Social Sciences. Maringá, v. 35, n. 2, p. 189199, July-Dec., 2013

Política e história em Caio Prado Júnior. São Luís: 1ª ed. UEMA, 2008.

NOVAIS, Fernando A. Portugal e Brasil na crise do Antigo Sistema Colonial (1777 - 1808). São Paulo: Hucitec, 1979. 
PRADO JÚNIOR, Caio. Formação do Brasil Contemporâneo: Colônia. 24a edição. São Paulo: Brasiliense, 1996.

PUJOL, Xavier Gil. "Centralismo e Localismo? Sobre as Relações Políticas e Culturais entre Capital e Territórios nas Monarquias Europeias dos Séculos XVI e XVII" IN: Penélope. Fazer e desfazer história. N. 6. (Setembro de 1991).

REIS, José Carlos. As identidades do Brasil: de Varnhagen a FHC. 8ed. Rio de Janeiro, Ed. FGV, 2006

SCHWARTZ, Stuart. "Mentalidades e estruturas sociais no Brasil colonial: uma resenha coletiva." In: Economia e Sociedade. Campinas, (13): 129-153, dez. 1999.

SIMONSEN, Roberto. História Econômica do Brasil. 3a ed. Editora do Senado Federal: 2005.

SODRÉ, Nelson Werneck. Formação histórica do Brasil. São Paulo: Brasiliense, 1962.

SOUZA, Laura de Mello e. O Sol e a Sombra. Política e administração na América portuguesa. São Paulo: Companhia das Letras, 2006.

Wallerstein Immanuel. Y a-t-il une crise du XVIle siècle ?. In: Annales. Économies, Sociétés, Civilisations. 34 année, N. 1, 1979.

WHITE, Hayden. Meta-história. A imaginação histórica do século XIX. Tradução José Laurênio de Melo. São Paulo: Edusp, 1992

WILLIAMS, Eric. Capitalism and slavery. North Carolina Press: 1994 [1944].

Sites

http://www.cmd.unb.br/biblioteca.html

http://www.jstor.org/

http://www.slavevoyages.org/voyage/search 